\title{
Carborane bis-pyridylalcohols as linkers for Coordination Polymers: Synthesis, Crystal Structures and Guest- Framework dependent Mechanical Properties
}

Min Ying Tsang, ${ }^{a}$ Sabina Rodríguez-Hermida, ${ }^{\mathrm{b}}$ Kyriakos C. Stylianou, ${ }^{\mathrm{b}}$ Fangchang Tan, ${ }^{\mathrm{a}}$ Divya Negi, ${ }^{\mathrm{a}}$ Francesc Teixidor, ${ }^{a}$ Clara Viñas, ${ }^{a}$ Duane Choquesillo-Lazarte, ${ }^{\mathrm{c}}$ Cristóbal Verdugo-Escamilla, ${ }^{\mathrm{c}}$ Miguel Guerrero, ${ }^{\mathrm{d}}$ Jordi Sort, ${ }^{\mathrm{d}, \mathrm{e}}$ Jordi Juanhuix, ${ }^{\mathrm{f}}$ Inhar Imaz, ${ }^{\mathrm{b}}$ Daniel Maspoch ${ }^{\mathrm{b}, \mathrm{e}^{*}}$ and José Giner Planas ${ }^{\mathrm{a}^{*}}$

${ }^{a}$ Institut de Ciència de Materials de Barcelona (ICMAB-CSIC), Campus UAB, 08193 Bellaterra, Spain.

${ }^{\mathrm{b}}$ Catalan Institute of Nanoscience and Nanotechnology (ICN2), CSIC and The Barcelona Institute of Science and Technology, Campus UAB, Bellaterra, 08193 Barcelona, Spain.

${ }^{c}$ Laboratorio de Estudios Cristalográficos, IACT, CSIC-Universidad de Granada, Av. de las Palmeras 4, E-18100 Armilla, Granada, Spain.

${ }^{\mathrm{d}}$ Departament de Física, Universitat Autònoma de Barcelona, E-08193 Bellaterra, Spain

${ }^{\mathrm{e}}$ ICREA, Pg. Lluís Companys 23, 08010 Barcelona, Spain.

${ }^{\mathrm{f}}$ Alba Synchrotron Light Facility, 08290 Cerdanyola del Vallés, Barcelona, Spain.

\begin{abstract}
We report the synthesis and characterization of six novel coordination polymers (CPs) based on $\mathrm{M}(\mathrm{II})$ (M: $\mathrm{Zn}$ and $\mathrm{Co}$ ), di-, tri- and tetracarboxylate linkers and two novel bispyridylalcohol 1,7-bis $\left\{(\right.$ piridin- $n$ '-yl)methanol $\}$-1,7-dicarba-closo-dodecaboranes $\left(n^{\prime}=3, \mathbf{L 1} ; n^{\prime}=\right.$ 4 , L2) ligands. The polycarboxylates are terephthalic acid $\left(\mathrm{H}_{2} \mathrm{BDC}\right), 1,3,5$-benzenetricarboxylic acid $\left(\mathrm{H}_{3} \mathrm{BTB}\right)$ and 1,2,4,5-tetrakis(4-carboxyphenyl)benzene $\left(\mathrm{H}_{4} \mathrm{TCPB}\right)$. Structural description of CPs reveals the flexibility of the carborane ligands and their ability to construct extended structures. The CP containing Co(II), BTB and $\mathbf{L} 2$ behaves as a crystalline sponge for a variety of guests, showing a higher affinity for aromatic guest molecules. Single-crystal nanoindentation experiments indicate that a high number of specific interactions between the guests and the CP framework results in a high elastic modulus and hardness values.
\end{abstract}




\section{Introduction}

Porous Coordination Polymers (CPs) or Metal-Organic Frameworks (MOFs) are a class of porous crystalline materials formed by the assembly of metal ions or metal clusters with different types of bridging organic linkers. ${ }^{1-4}$ Multiple network structures with various topologies can be prepared by the appropriate choice of metal ion geometry and the binding mode of the bridging ligand. The primary choice of the organic part has been polycarboxylates, polypyridines, and organic ligands that possess both carboxylate groups and $\mathrm{N}$ donor atoms. Thus, the chemistry of CPs has been dominated by these ligands. Sometimes, the above-mentioned ligands are simultaneously used to generate mixed-ligand three-dimensional (3D) CPs. ${ }^{5}$ The majority of these CPs are formed by connecting metal-polycarboxylate layers through pyridyl-based ligands. This approach allows higher flexibility in terms of pore size and introduction of functional groups. In this regard, MOFs can be easily tuned and amenable to a wide variety of guest compounds, through host-guest interactions. ${ }^{6-8}$ Preferential arrangement of guest molecules within CPs has enabled the structural determination of molecules that did not crystallized otherwise. The latter method, known as the crystalline sponge method, ${ }^{6}$ rely on specific host-guest interactions that renders the guest molecules regularly ordered. ${ }^{7}$ Such host-guest interactions are being explored for a variety of applications. ${ }^{9}$ In light of the imminence of these materials applications, mechanical properties, which are critical to the industrial manufacturing and processing, need to be taken into account. ${ }^{10,11}$

The icosahedral closo-carboranes (dicarba-closo-dodecaboranes; $\left(\mathrm{C}_{2} \mathrm{~B}_{10} \mathrm{H}_{12}\right)$ ) are an interesting class of exceptionally stable boron-rich clusters that can be prepared on the kilogram scale, and that can be modified at different vertices via chemical reactions. ${ }^{12-17}$ Three isomeric forms are known: ortho, meta and para, which are differentiated by the position of the carbons in the cluster (Scheme 1). The average size of the carboranes (141-148 $\AA^{3}$ ) is comparable to that of adamantane $\left(136 \AA^{3}\right.$ ) and is significantly larger (40\%) than the phenyl ring rotation envelope (102 $\AA^{3}$ ). The spherical feature of these molecules, with slightly polarized hydrogen atoms, and the presence of the hydride-like hydrogens at the B-H vertexes make the carboranes very hydrophobic. In addition to that, the high thermal and chemical stability, acceptor character and 3D nature of the icosahedral carborane clusters make them valuable ligands in coordination chemistry. ${ }^{18-23}$ For example, Mirkin and co-workers explored the use of di-, tri- and tetra-carboxylic acid derivatives of para-carborane (I to IV in Scheme 1) for CP synthesis, providing a series of CPs exhibiting unprecedented stabilities with respect to thermal degradation, inherited from the carborane moiety. ${ }^{24-30}$ Some of the CPs including these polycarboxylato $p$-carborane-based linkers showed gas uptake properties and excellent selectivity for $\mathrm{CO}_{2} / \mathrm{CH}_{4}$ mixtures. Jin and co-workers also constructed CPs based on the dicarboxylic acid derivatives of para- but also of meta-carborane 
linker ( $\mathbf{V}$ in Scheme 1), and studied their adsorption and luminescence properties. ${ }^{31,32}$ More recently, dicarboxylic and tricarboxylic derivatives of the smaller carborane closo-1,10- $\mathrm{C}_{2} \mathrm{~B}_{8} \mathrm{H}_{10}$ were also incorporated into porous CPs. ${ }^{26,33}$

Scheme 1. Graphical representation of the carborane isomers $\left(\right.$ closo $\left.-\mathrm{C}_{2} \mathrm{~B}_{10} \mathrm{H}_{12}\right)$ and their derivatives used as linkers to form CPs.

The hydrophobic properties of carboranes, exploited in a number of medicinal applications, can potentially enhance the hydrolytic stability of CPs. In fact, we have recently communicated the first example that uses a non-carboxylic derivative of ortho-carborane (VI in Scheme 1) as a linker to form a $\mathrm{Zn}(\mathrm{II})$-based $\mathrm{CP} .{ }^{34} \mathrm{In}$ this $\mathrm{CP}$, the $o$-carborane based ligand $\mathbf{V I}$ acted as a bridging linker to connect $\mathrm{Zn}$ (II)-1,4-benzenedicarboxylate layers, giving a porous hydrophobic and water stable 3D framework. ${ }^{34}$ In our continuing exploration of the synthetic and structural chemistry of these carborane-based molecules, we have now synthesized two new disubstituted $m$ carboranylpyridylalcohols ( $\mathbf{L} 1$ and $\mathbf{L} 2$ in Scheme 2). It is readily envisaged that these carborane based $\mathrm{N}$-donor ditopic ligands are able to display various ligating topologies depending on the relative orientation of the pyridyl rings with respect to the carboranyldiol spacer. Consequently, the resulting $\mathrm{CP}$ architectures should be dependent on the ligand conformation and nitrogen position in the aromatic ring. The ligand flexibility is expected to be higher in the case of the $m$-carborane derivatives as the substituted carbons are farther away than in the $o$-carborane ones (VI in Scheme 1). We are particularly interested in the effect that the flexibility of these $\mathrm{N}$-donor ditopic ligands 
may have on the crystal structures and networks but also in the potential use of these disubstituted carboranes as linkers in CPs. Herein, we report the synthesis of two novel carboranylalcohol 1,7bis $\left\{\right.$ (piridin- $n^{\prime}$-yl)methanol $\}$-1,7-dicarba-closo-dodecaboranes $\left(n^{\prime}=3, \mathbf{L 1} ; n^{\prime}=4, \mathbf{L 2}\right)$ ligands, and their reaction with different di-, tri- and tetratopic carboxylic acids and metal salts to form six new extended CPs (Scheme 2). We present the syntheses, crystal structures, thermal properties and water stability of the new CPs. In addition, we show the crystal sponge behavior and guest dependent mechanical properties of one of these CPs.

Scheme 2. Representation of the ligands employed in this work and of the synthesis of CPs 1-6.
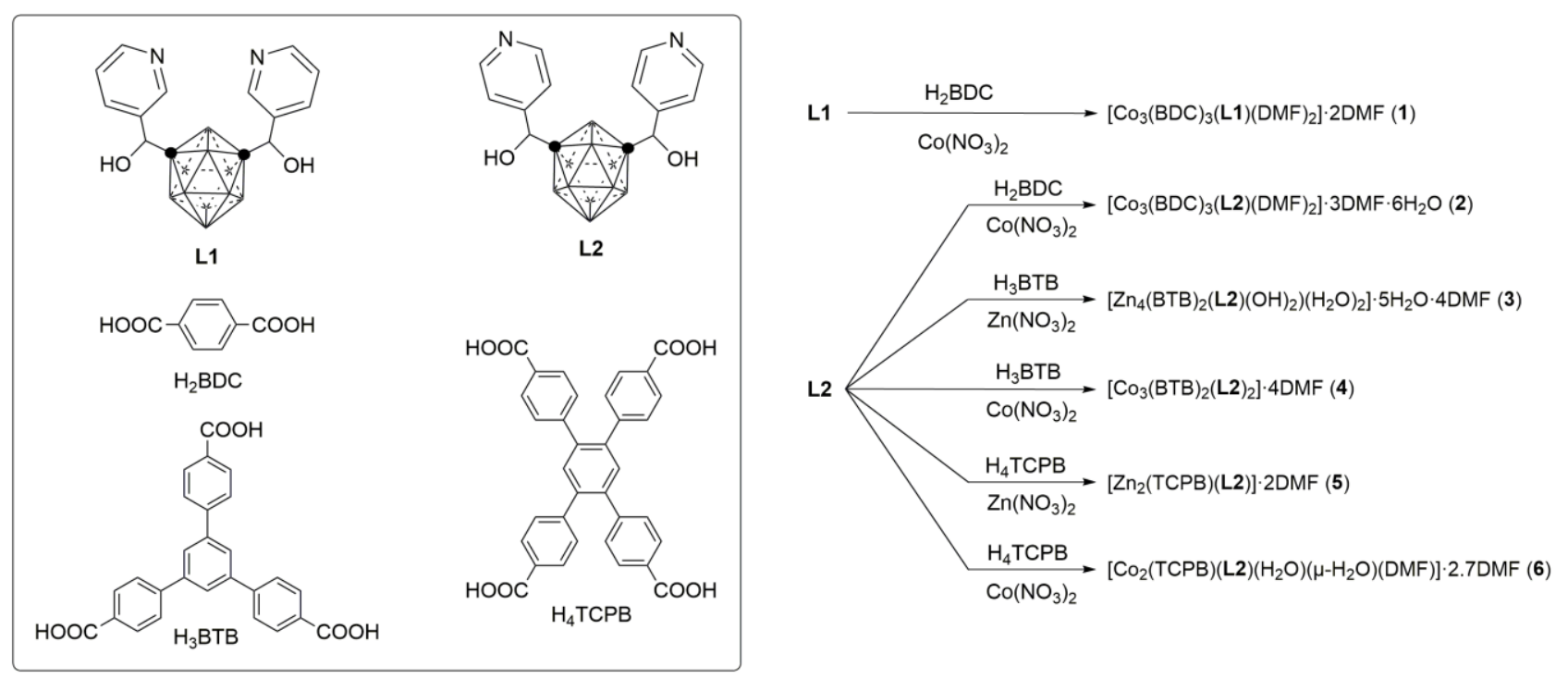

\section{EXPERIMENTAL SECTION}

Materials and Characterization. Syntheses for the carboranylalcohol ligands were carried out under nitrogen atmosphere in round-bottomed flasks equipped with a magnetic stirring bar, capped with a septum. Tetrahydrofurane (THF) was distilled from Na/benzophenone. CP syntheses were done in air. All chemicals were commercially available and used as received. IR ATR spectra were recorded on a Perkin-Elmer Spectrum One spectrometer. ${ }^{1} \mathrm{H},{ }^{13} \mathrm{C}$ and ${ }^{11} \mathrm{~B}$ NMR spectra were recorded respectively at 300, 75 and $96 \mathrm{MHz}$ with a Bruker Advance-300 spectrometer in deuterated dimethylsulfoxide, unless denoted, and referenced to the residual solvent peak for ${ }^{1} \mathrm{H}$ and ${ }^{13} \mathrm{C}$ NMR or to $\mathrm{BF}_{3} \cdot \mathrm{OEt}_{2}$ as an external standard for ${ }^{11} \mathrm{~B}$ NMR. Chemical shifts are reported in ppm and coupling constants in Hertzs. Multiplets nomenclature is as follows: s, singlet; d, doublet; t, triplet; br, broad; m, multiplet. Elemental analyses were obtained by a CarboErba EA1108 microanalyzer (Universidad Autónoma de Barcelona). The mass spectra were recorded in the negative ion mode using a Bruker Biflex MALDI-TOF-MS [ $\mathrm{N}_{2}$ laser; $\lambda_{\text {exc }} 337 \mathrm{~nm}$ (0.5 ns pulses); 
voltage ion source $20.00 \mathrm{kV}$ (Uis1) and $17.50 \mathrm{kV}$ (Uis2)] with 3,5-dimethoxy-4-hydroxycinnamic acid as the matrix. TGA-DSC from NETZSCH (heating rate: $10^{\circ} \mathrm{C} / \mathrm{min}$; temperature range: 25 to $\left.800{ }^{\circ} \mathrm{C}\right)$. Gas sorption $\left(\mathrm{CO}_{2} / 195 \mathrm{~K}\right.$ and $\left.\mathrm{N}_{2} / 77 \mathrm{~K}\right)$ measurements for $\mathbf{3}$ were performed using an AutosorbIQ (Quantachrome Instruments). Field-Emission Scanning Electron Microscopy (FESEM) images were collected using a Quanta 650F Environmental Scanning Electron Microscopy (Field Emission Inc, USA). Powder X-ray Diffraction (PXRD) patterns were recorded at room temperature on an X'Pert PRO MPD diffractometer (PanAnalytical) for $\mathrm{Cu} K \alpha(\lambda=1.5405 \AA)$.

\section{Synthesis of the ligands and compounds}

1,2-bis $\{($ pyridin-3'-yl)methanol\}-1,7-dicarba-closo-dodecaborane (L1). $n$-BuLi $(1.02 \mathrm{~mL}$, $1.44 \mathrm{M}$ in hexane, $1.47 \mathrm{mmol}$ ) was added dropwise to a solution of $m$-carborane (105.8 $\mathrm{mg}, 0.73$ $\mathrm{mmol})$ in $\mathrm{Et}_{2} \mathrm{O}(10 \mathrm{~mL})$ at $0{ }^{\circ} \mathrm{C}$ (ice/water bath) under nitrogen atmosphere. The mixture was stirred at $0{ }^{\circ} \mathrm{C}$ for $30 \mathrm{~min}$ and at room temperature for $1 \mathrm{~h}$ to give a pale yellow suspension. The flask was then cooled to $-63{ }^{\circ} \mathrm{C}$ (chloroform/liquid $\mathrm{N}_{2}$ ), whereupon a solution of 3-pyridinecarboxaldehyde (157.1 mg, $0.14 \mathrm{~mL}, 1.47 \mathrm{mmol})$ in THF $(1 \mathrm{~mL})$ was added. The resulting pale yellow solution was stirred at $-63{ }^{\circ} \mathrm{C}$ for $4 \mathrm{~h}$. Then, a saturated aqueous solution of $\mathrm{NH}_{4} \mathrm{Cl}(10 \mathrm{~mL})$ was added at $-63{ }^{\circ} \mathrm{C}$. The resulting mixture was taken out of the cooling bath and allowed to warm naturally to room temperature while stirring. The aqueous phase was then extracted with $\mathrm{Et}_{2} \mathrm{O}(3 \times 20 \mathrm{~mL})$, and the organic phases were dried over $\mathrm{MgSO}_{4}$, filtered, and evaporated to dryness. The resultant dark yellow oil was washed with $n$-pentane $(2 \times 10 \mathrm{~mL})$. Then, fresh $n$-pentane was added and the mixture was treated with ultrasound for c.a. 30 minutes. Afterwards, the slightly colored pentane supernatant was removed. The same procedure was repeated until a light yellow solid was obtained (2-3 times). After removing the solvent, the yellow solid was dried under vacuum affording pure L1 (200.9 mg, 0.56 mmol, 77 \%). ${ }^{1} \mathrm{H}$ NMR: 8.50 (brs, $\left.2 \mathrm{H}, \mathrm{C}_{5} \mathrm{H}_{4} \mathrm{~N}\right), 7.64$ (brs, 2H, $\left.\mathrm{C}_{5} \mathrm{H}_{4} \mathrm{~N}\right), 7.63$ (d, J = $\left.7.8,2 \mathrm{H}, \mathrm{C}_{5} \mathrm{H}_{4} \mathrm{~N}\right), 7.36\left(\mathrm{dd}, \mathrm{J}=8.1 \mathrm{~Hz}, 4.8 \mathrm{~Hz}, 2 \mathrm{H}, \mathrm{C}_{5} \mathrm{H}_{4} \mathrm{~N}\right), 6.58(\mathrm{~d}, \mathrm{~J}=5.1 \mathrm{~Hz}, 2 \mathrm{H}, \mathrm{OH}), 4.89$ (d, J $=5.4 \mathrm{~Hz}, 2 \mathrm{H}, \mathrm{CHOH}) \cdot{ }^{11} \mathrm{~B}$ NMR: 0 to $-20 \mathrm{ppm}(\mathrm{br}, 10 \mathrm{~B}) \cdot{ }^{13} \mathrm{C} \mathrm{NMR}: 148.9\left(\mathrm{C}_{5} \mathrm{H}_{4} \mathrm{~N}\right), 147.8$ $\left(\mathrm{C}_{5} \mathrm{H}_{4} \mathrm{~N}\right), 136.9\left(\mathrm{C}_{5} \mathrm{H}_{4} \mathrm{~N}\right), 134.0\left(\mathrm{C}_{5} \mathrm{H}_{4} \mathrm{~N}\right), 123.3\left(\mathrm{C}_{5} \mathrm{H}_{4} \mathrm{~N}\right), 81.8\left(\mathrm{C}_{\text {cluster }}\right), 71.2(\mathrm{CHOH})$. IR (ATR; selected bands; $\left.\mathrm{cm}^{-1}\right): v 3070(\mathrm{OH}), 2602(\mathrm{BH})$. MALDI-TOF, m/z: M: $359.4[\mathrm{M}+\mathrm{H}]^{+}$. Elemental analysis (\%) calculated for $\mathrm{B}_{10} \mathrm{C}_{14} \mathrm{O}_{2} \mathrm{~N}_{2} \mathrm{H}_{22}$ : C 46.9, $\mathrm{H}$ 6.2, $\mathrm{N}$ 7.8; found $\mathrm{C} 46.7, \mathrm{H}$ 6.4, N 7.5.

1,2-bis $\{($ pyridin-4'-yl)methanol\}-1,7-dicarba-closo-dodecaborane (L2). L2 was synthesized using the same procedure described above, but using $n$-BuLi $(4.49 \mathrm{~mL}, 1.55 \mathrm{M}$ in hexane, 7.0 mmol), $m$-carborane (502.4 mg, $3.5 \mathrm{mmol})$, THF (25 mL), 4-pyridinecarboxaldehyde $(0.7 \mathrm{~mL}, 7.0$ mmol), and an acetonitrile/liquid $\mathrm{N}_{2}$ cooling bath $\left(-41^{\circ} \mathrm{C}\right)$. The resulting pale-yellow solution was stirred at $-41{ }^{\circ} \mathrm{C}$ for $4 \mathrm{~h}$. Then, a saturated aqueous solution of $\mathrm{NH}_{4} \mathrm{Cl}(10 \mathrm{~mL})$ was added at $-41{ }^{\circ} \mathrm{C}$. 
The resulting mixture was taken out of the cooling bath and allowed to warm naturally to room temperature while stirring. Then, $\mathrm{Et}_{2} \mathrm{O}(15 \mathrm{~mL})$ was added while stirring. A white solid precipitated after 20-25 min, which was filtrated, washed with water and $\mathrm{Et}_{2} \mathrm{O}$, and dried under vacuum affording pure $\mathbf{L 2}(1.16 \mathrm{~g}, 3.23 \mathrm{mmol}, 92.3 \%) .{ }^{1} \mathrm{H}$ NMR $8.53\left(\mathrm{~d}, \mathrm{~J}=6.0 \mathrm{~Hz}, 4 \mathrm{H}, \mathrm{C}_{5} \mathrm{H}_{4} \mathrm{~N}\right), 7.23(\mathrm{~d}, \mathrm{~J}$ $\left.=6.0 \mathrm{~Hz}, 4 \mathrm{H}, \mathrm{C}_{5} \mathrm{H}_{4} \mathrm{~N}\right), 6.64(\mathrm{~d}, \mathrm{~J}=5.1 \mathrm{~Hz}, 2 \mathrm{H}, \mathrm{OH}), 4.83(\mathrm{~d}, \mathrm{~J}=5.1,2 \mathrm{H}, \mathrm{CHOH}) .{ }^{11} \mathrm{~B} \mathrm{NMR}:-$ 11.36 (br, 10B). ${ }^{13} \mathrm{C}$ NMR: $149.9\left(\mathrm{C}_{5} \mathrm{H}_{4} \mathrm{~N}\right), 149.3\left(\mathrm{C}_{5} \mathrm{H}_{4} \mathrm{~N}\right), 127.8\left(\mathrm{C}_{5} \mathrm{H}_{4} \mathrm{~N}\right), 81.0\left(\mathrm{C}_{\text {cluster }}\right), 72.2$ (CHOH). IR (ATR; selected bands; $\mathrm{cm}^{-1}$ ): v $3093(\mathrm{OH}), 2590(\mathrm{BH})$. MALDI-TOF, m/z: M: 359.4 $[\mathrm{M}+\mathrm{H}]^{+}$. Elemental analysis (\%) calculated for $\mathrm{B}_{10} \mathrm{C}_{14} \mathrm{O}_{2} \mathrm{~N}_{2} \mathrm{H}_{22}$ : C 46.9, H 6.2, N 7.8; found C 46.5, H 6.2, N 7.6.

$\left[\mathrm{Co}_{3}(\mathrm{BDC})_{3}(\mathrm{L1})(\mathrm{DMF})_{2}\right] \cdot 2 \mathrm{DMF}(\mathbf{1}) . \mathrm{Co}\left(\mathrm{NO}_{3}\right)_{2} \cdot 6 \mathrm{H}_{2} \mathrm{O}(48.7 \mathrm{mg}, 0.167 \mathrm{mmol})$ was mixed with L1 (20 mg, $0.054 \mathrm{mmol}$ ) and $\mathrm{H}_{2} \mathrm{BDC}(13.8 \mathrm{mg}, 0.167 \mathrm{mmol})$ in $4 \mathrm{~mL}$ of DMF/ethanol (1:1). This mixture was sonicated until all solids were uniformly dissolved, followed by heating at $100{ }^{\circ} \mathrm{C}$ for 24 h. Violet flake-like crystals of 1 were collected and washed with DMF (45.3 mg, 68.5 \%). IR (ATR; selected bands; $\mathrm{cm}^{-1}$ ): $v 3426(\mathrm{OH}) ; 2931,2861(\mathrm{CH}) ; 2531(\mathrm{BH}) ; 1657$ (C=O from DMF); 1617 ( $\mathrm{C}=\mathrm{O}$ from carboxylate). Elemental analysis (\%) calculated for $\mathrm{Co}_{3} \mathrm{C}_{50} \mathrm{H}_{62} \mathrm{~B}_{10} \mathrm{~N}_{6} \mathrm{O}_{18}: \mathrm{C} 45.5, \mathrm{H}$ 4.7, N 6.4; Found: C 45.0, H 4.6, N 6.2.

$\left[\mathrm{Co}_{3}(\mathrm{BDC})_{3}(\mathrm{L2})(\mathrm{DMF})_{2}\right] \cdot 3 \mathrm{DMF} \cdot \mathbf{6 H}_{2} \mathrm{O}$ (2). 2 was obtained by mixing $\mathrm{Co}\left(\mathrm{NO}_{3}\right)_{2} \cdot 6 \mathrm{H}_{2} \mathrm{O}(48.7$ $\mathrm{mg}, 0.167 \mathrm{mmol}), \mathbf{L} 2(20 \mathrm{mg}, 0.054 \mathrm{mmol})$ and $\mathrm{H}_{2} \mathrm{BDC}(13.8 \mathrm{mg}, 0.167 \mathrm{mmol})$ in $4 \mathrm{~mL}$ of DMF/ethanol (1:1). This mixture was sonicated until all solids were uniformly dissolved, followed by heating at $100{ }^{\circ} \mathrm{C}$ for $24 \mathrm{~h}$. Violet flake-like crystals of 2 were collected and washed with DMF (50 mg, $61.7 \%)$. IR (ATR; selected bands; $\left.\mathrm{cm}^{-1}\right): v 3200(\mathrm{OH}) ; 2963,2923,2885(\mathrm{CH}) ; 2617$ $(\mathrm{BH}) ; 1656(\mathrm{C}=\mathrm{O}$ from $\mathrm{DMF}) ; 1598$ (C=O from carboxylate). Elemental analysis (\%) calculated for $\mathrm{Co}_{3} \mathrm{C}_{53} \mathrm{H}_{81} \mathrm{~B}_{10} \mathrm{~N}_{7} \mathrm{O}_{25}$ : C 42.4, H 5.4, N 6.5; found: C 42.0, H, 5.0, N 7.0.

$\left.\left[\mathrm{Zn}_{4}(\mathrm{BTB})_{2}(\mathrm{L2})(\mathrm{OH})_{2}\right)\left(\mathrm{H}_{2} \mathrm{O}\right)_{2}\right] \cdot \mathbf{5} \mathrm{H}_{2} \mathrm{O} \cdot 4 \mathrm{DMF}(3) .3$ was obtained by mixing $\mathrm{Zn}\left(\mathrm{NO}_{3}\right)_{2} \cdot 6 \mathrm{H}_{2} \mathrm{O}$ (33.2 mg, $0.112 \mathrm{mmol}$ ), L2 (10 mg, $0.027 \mathrm{mmol}$ ) and $\mathrm{H}_{3} \mathrm{BTB}$ (23.6 mg, $0.054 \mathrm{mmol}$ ) in $2 \mathrm{~mL}$ of DMF/ethanol/ $\mathrm{H}_{2} \mathrm{O}$ (2:1:1). This mixture was sonicated until all solids were uniformly dissolved, followed by heating at $85{ }^{\circ} \mathrm{C}$ for $48 \mathrm{~h}$. Colorless block crystals of 3 were collected and washed with DMF (48.5 mg, 89\%). IR (ATR; selected bands; $\mathrm{cm}^{-1}$ ): v $3350(\mathrm{OH}) ; 2933,2964,2865$ (CH); 2617 , $2554(\mathrm{BH}) ; 1660(\mathrm{C}=\mathrm{O}$ from $\mathrm{DMF}) ; 1610,1585$ (C=O from carboxylate). Elemental analysis $(\%)$ calculated for $\mathrm{Zn}_{4} \mathrm{C}_{80} \mathrm{H}_{88} \mathrm{O}_{23} \mathrm{~B}_{10} \mathrm{~N}_{6}$ : C 49.5, H 4.9, N 4.3; Found: C 50.0, H 4.7, N 4.7.

[Co3 $\left.(\mathbf{B T B})_{2}(\mathbf{L 2})_{2}\right] \cdot 4 \mathrm{DMF}(4) . \mathrm{Co}\left(\mathrm{NO}_{3}\right)_{2} \cdot 6 \mathrm{H}_{2} \mathrm{O}(31.43 \mathrm{mg}, 0.108 \mathrm{mmol})$ was mixed with L2 (10 $\mathrm{mg}, 0.027 \mathrm{mmol})$ and $\mathrm{H}_{3} \mathrm{BTB}(23.6 \mathrm{mg}, 0.054 \mathrm{mmol})$ in $2 \mathrm{~mL}$ of DMF/ethanol/ $\mathrm{H}_{2} \mathrm{O}(2: 1: 1)$. This mixture was sonicated until all solids were uniformly dispersed, followed by heating at $100{ }^{\circ} \mathrm{C}$ for 48 h. Red-violet crystals of 4 were collected and washed with DMF (28 mg, 81.7\%). IR (ATR; 
selected bands; $\left.\mathrm{cm}^{-1}\right): \vee 3298(\mathrm{OH}) ; 2931,2829(\mathrm{CH}) ; 2607(\mathrm{BH}) ; 1662(\mathrm{C}=\mathrm{O}$ from DMF); 1602 $\left(\mathrm{C}=\mathrm{O}\right.$ from carboxylate). Elemental analysis $(\%)$ calculated for $\mathrm{Co}_{3} \mathrm{C}_{94} \mathrm{H}_{102} \mathrm{~B}_{20} \mathrm{~N}_{8} \mathrm{O}_{20}$ : C 53.4, H 5.0, N 5.2; Found: C 53.2, H 5.1, N 5.3.

[ $\mathrm{Zn}_{2}$ (TCPB)(L2)]·2DMF (5). 5 was obtained by mixing $\mathrm{Zn}\left(\mathrm{NO}_{3}\right)_{2} \cdot 6 \mathrm{H}_{2} \mathrm{O}$ (11.06 mg, 0.037 mmol), L2 (20 mg, $0.054 \mathrm{mmol})$ and $\mathrm{H}_{4} \mathrm{TCPB}(20.8 \mathrm{mg}, 0.037 \mathrm{mmol})$ in $2 \mathrm{~mL}$ of DMF/ethanol/ $\mathrm{H}_{2} \mathrm{O}(2: 1: 1)$, and one drop of concentrated $\mathrm{HCl}$. This mixture was sonicated until all solids were uniformly dissolved, followed by heating at $80{ }^{\circ} \mathrm{C}$ for $48 \mathrm{~h}$. Pale yellow crystals of 5 were filtered and washed with DMF (14.9 mg, 67.4\%). IR (ATR; selected bands; $\mathrm{cm}^{-1}$ ): $v 3434$ $(\mathrm{OH})$; 2927, $2859(\mathrm{CH})$; 2604(BH); 1653 (C=O from DMF); 1609 (C=O from carboxylate). Elemental analysis (\%) calculated for $\mathrm{C}_{54} \mathrm{H}_{54} \mathrm{~B}_{10} \mathrm{~N}_{4} \mathrm{O}_{12} \mathrm{Zn}_{2}$ : C 54.51, H 4.57, N 4.71; Found: C 54.70, H 4.58, N 4.70.

$\left[\mathrm{Co}_{2}(\mathrm{TCPB})(\mathrm{L2})\left(\mathrm{H}_{2} \mathrm{O}\right)\left(\mathrm{H}_{2} \mathrm{O}\right)(\mathrm{DMF})\right] \cdot 2.7 \mathrm{DMF}(6) .6$ was obtained by mixing $\mathrm{Co}\left(\mathrm{NO}_{3}\right)_{2} \cdot 6 \mathrm{H}_{2} \mathrm{O}$ (16.3 mg, $0.056 \mathrm{mmol}), \mathbf{L 2}(10 \mathrm{mg}, 0.027 \mathrm{mmol})$ and $\mathrm{H}_{4}$ TCPB $(15.6 \mathrm{mg}, 0.027 \mathrm{mmol})$ in $2 \mathrm{~mL}$ of DMF/ethanol/ $\mathrm{H}_{2} \mathrm{O}$ (2:1:1). This mixture was sonicated until all solids were uniformly dissolved, followed by heating at $80{ }^{\circ} \mathrm{C}$ for $48 \mathrm{~h}$. Violet crystals of 6 were collected and washed with DMF (29.73 mg, 79.8\%). IR (ATR; selected bands; $\left.\mathrm{cm}^{-1}\right): v 3374(\mathrm{OH}) ; 2925,2872(\mathrm{CH}) ; 2616(\mathrm{BH})$; $1647(\mathrm{C}=\mathrm{O}$ from $\mathrm{DMF}) ; 1608(\mathrm{C}=\mathrm{O}$ from carboxylate). Elemental analysis (\%) calculated for $\mathrm{C}_{60} \mathrm{H}_{72} \mathrm{~B}_{10} \mathrm{Co}_{2} \mathrm{~N}_{6} \mathrm{O}_{16}$ : C 53.02, H 5.34, N 6.18; Found: C 51.50, H 5.20, N 6.05.

Crystallography. Measured crystals were prepared under inert conditions immersed in perfluoropolyether or paratone as protecting oil for manipulation. Suitable crystals were mounted on MiTeGen Micromounts ${ }^{\mathrm{TM}}$, and these samples were used for data collection. Crystallographic data for $\mathbf{1}$ and $\mathbf{3}$ were collected at 100K at XALOC beamline at ALBA synchrotron ${ }^{35}(\lambda=0.79000$ $\AA$ for 1 and $\lambda=0.82653 \AA$ for 3 ). Data for 3 were indexed, integrated and scaled using the XDS and IMOSFLM programs, and absorption corrections were not applied. For 1, data were processed with CrysAlisPro programs and corrected for absorption using the SCALE3 ABSPACK algorithm implemented in CrysAlisPro. Crystallographic data for 4, 5 and $\mathbf{6}$ were collected with a Bruker D8 Venture diffractometer, processed with $\mathrm{APEX} 2^{36}$ program and corrected for absorption using SADABS. ${ }^{37}$ The structures were solved by direct methods and subsequently refined by correction of $\mathrm{F}^{2}$ against all reflections. ${ }^{38}$ All non-hydrogen atoms were refined with anisotropic thermal parameters by full-matrix least-squares calculations on $\mathrm{F}^{2} .{ }^{39}$ Hydrogen atoms were inserted at calculated positions and constrained with isotropic thermal parameters in $\mathbf{3}$. For the rest of structures, all hydrogen atoms were located in difference Fourier maps and included as fixed contributions riding on attached atoms with isotropic thermal displacement parameter $1.2(\mathrm{C}-\mathrm{H}, \mathrm{B}-$ $\mathrm{H})$ or $1.5(\mathrm{O}-\mathrm{H})$ times those of the respective atom. In $\mathbf{3}$, the disorder associated with the oxygen 
atom of the crystallized water molecule hindered the localization of its hydrogen atoms. The contribution of the disordered solvent molecules to the diffraction pattern could not be rigorously included in the model and were consequently removed with the SQUEEZE routine of PLATON (for 3) or with the mask tool implemented in Olex2 (for 4, 5 and 6). 1 was treated as a two component non-merohedral twin, the exact twin matrix identified by the integration program was found to be 1 $00.50-1000-1$. The structure of 1 was solved using direct methods with only the nonoverlapping reflections of component 1 . The structure was refined using the HKLF 5 routine with all reflections of component 1 (including the overlapping ones), resulting in a BASF value of 0.373(4).

Attempts to obtain suitable single crystals of 2 were unsuccessful. However, it was possible to obtain the unit cell parameters from its powder pattern by comparison with that for $\mathbf{1}$, assuming that both compounds crystallize in the monoclinic $C 2 / c$ space group and due to the similarity between the powder data for both compounds. Le Bail refinement was carried out with the software Topas 4.2 (Bruker AXS) and using the cell parameters for 1. The refinement yielded the following cell parameters: $C 2 / \mathrm{c}, \mathrm{a}=37.907, \mathrm{~b}=9.067, \mathrm{c}=17.420$ and $\beta=95.135$, with excellent agreement indicators $(\operatorname{Rwp}=1.22 \%, \mathrm{Rp}=2.29 \%, \operatorname{Rexp}=1.67 \%)$. A summary of crystal data is reported in Table 1, and the selected bond distances and angles for L2 (Figure S1), 1 and 3-6 are listed in Table S2. 


\begin{tabular}{|c|c|c|c|c|c|c|c|}
\hline Compound & L2 & 1 & 2 & 3 & 4 & 5 & 6 \\
\hline $\begin{array}{l}\text { Empirical } \\
\text { formula }\end{array}$ & $\mathrm{C}_{14} \mathrm{H}_{22} \mathrm{~B}_{10} \mathrm{~N}_{2} \mathrm{O}_{2}$ & $\begin{array}{l}\mathrm{C}_{50} \mathrm{H}_{62} \mathrm{~B}_{10} \\
\mathrm{~N}_{6} \mathrm{O}_{18} \mathrm{Co}_{3}\end{array}$ & & $\begin{array}{l}\mathrm{C}_{68} \mathrm{H}_{45} \mathrm{~B}_{10} \\
\mathrm{~N}_{2} \mathrm{O}_{17} \mathrm{Zn}_{4}\end{array}$ & $\begin{array}{l}\mathrm{C}_{88} \mathrm{H}_{88} \mathrm{~B}_{20} \\
\mathrm{~N}_{6} \mathrm{O}_{18} \mathrm{Co}_{3}\end{array}$ & $\begin{array}{l}\mathrm{C}_{72} \mathrm{H}_{96} \mathrm{~B}_{10} \\
\mathrm{~N}_{10} \mathrm{O}_{18} \mathrm{Zn}_{2}\end{array}$ & $\begin{array}{l}\mathrm{C}_{59.10} \mathrm{H}_{67.90} \mathrm{~B}_{10} \\
\mathrm{~N}_{5.70} \mathrm{O}_{15.70} \mathrm{Co}_{2}\end{array}$ \\
\hline Formula weight & 358.44 & 1319.95 & & 1540.71 & 1910.63 & 1628.42 & 1335.25 \\
\hline Crystal system & Tetragonal & Monoclinic & Monoclinic & Monoclinic & Triclinic & Triclinic & Monoclinic \\
\hline Space group & $\mathrm{P} 4{ }_{1} 2_{1} 2$ & $\mathrm{C} 2 / \mathrm{c}$ & $\mathrm{C} 2 / \mathrm{c}$ & Pn & $\mathrm{P}-1$ & $\mathrm{P}-1$ & $\mathrm{P} 2_{1} / \mathrm{c}$ \\
\hline \multicolumn{8}{|c|}{ Unit cell dimensions } \\
\hline $\mathrm{a}(\AA)$ & $7.51260(10)$ & $34.542(7)$ & 37.907 & $18.5945(10)$ & $14.9086(4)$ & $11.6364(5)$ & $16.2470(9)$ \\
\hline $\mathrm{b}(\AA)$ & & $9.5651(19)$ & 9.066 & $8.0800(5)$ & $15.3237(4)$ & $15.5850(6)$ & $21.0403(9)$ \\
\hline c $(\AA)$ & $33.7525(6)$ & $18.011(4)$ & 17.420 & $30.2904(19)$ & $15.6621(5)$ & $18.8230(8)$ & $22.8395(11)$ \\
\hline$\alpha(\operatorname{deg})$ & & & & & $67.5200(10)$ & $86.4230(18)$ & \\
\hline$\beta(\operatorname{deg})$ & & 97.71(3) & 95.135 & $90.819(2)$ & $62.9120(10)$ & $82.8690(19)$ & $105.811(2)$ \\
\hline$\gamma(\operatorname{deg})$ & & & & & $69.2370(10)$ & $89.7220(19)$ & \\
\hline $\mathrm{V}\left(\AA^{3}\right)$ & $1904.96(5)$ & $5897(2)$ & 5962.6 & $4550.5(5)$ & $2871.90(15)$ & $3380.6(2)$ & $7512.1(6)$ \\
\hline $\mathrm{Z}$ & 4 & 4 & & 2 & 1 & 2 & 4 \\
\hline $\mathrm{F}(000)$ & 744 & 2716 & & 1564 & 983 & 1704 & 2768 \\
\hline$\theta$ (range) & $5.24-66.58$ & $2.46-28.05$ & & $1.277-25.023$ & $2.629-28.321$ & $2.370-66.598$ & $2.334-25.060$ \\
\hline $\begin{array}{l}\text { Max./min. } \\
\text { transmission }\end{array}$ & $0.9728 / 0.9264$ & $0.7467 / 0.4052$ & & $0.7452 / 0.2826$ & $0.7457 / 0.6447$ & $0.7528 / 0.6338$ & $0.7452 / 0.2826$ \\
\hline Ind refln $\left(\mathrm{R}_{\mathrm{int}}\right)$ & $1666(0.0481)$ & $5155(0.0594)$ & & $15879(0.1216)$ & $14224(0.0336)$ & $11752(0.0509)$ & $12998(0.1505)$ \\
\hline $\begin{array}{l}\text { Final } \mathrm{R} \text { indices } \\
{[\mathrm{I}>2 \sigma(\mathrm{I})]}\end{array}$ & $\begin{array}{l}\mathrm{R} 1=0.0472 \\
\mathrm{wR} 2=0.1199\end{array}$ & $\begin{array}{l}\mathrm{R} 1=0.0781 \\
\mathrm{wR} 2=0.2264\end{array}$ & & $\begin{array}{l}\mathrm{R} 1=0.0759 \\
\mathrm{wR} 2=0.1858\end{array}$ & $\begin{array}{l}\mathrm{R} 1=0.0388 \\
\mathrm{wR} 2=0.1142\end{array}$ & $\begin{array}{l}\mathrm{R} 1=0.0736 \\
\mathrm{wR} 2=0.1979\end{array}$ & $\begin{array}{l}\mathrm{R} 1=0.0678 \\
\mathrm{wR} 2=0.1790\end{array}$ \\
\hline
\end{tabular}




\section{RESULT AND DISCUSSION}

Synthesis and Characterization. Following our previous reports, ${ }^{20,40}$ two new bis-pyridylmethyl alcohols derived from the $m$-carborane cluster, L1 and L2 (Scheme 2), were prepared by the reaction of dilithiated $m$-carborane with the corresponding aromatic aldehydes at low temperature and isolated in high yields (77-92\%). Both alcohols were fully characterized by standard spectroscopic and analytical techniques. ${ }^{20}$ In addition, the molecular structure of L2 was unequivocally established by single crystal X-ray diffraction (SCXRD) (Figures S1-2), which was in agreement with the NMR data. Solvothermal reactions (DMF/EtOH or DMF/EtOH/ $\mathrm{H}_{2} \mathrm{O}$ mixtures at $85{ }^{\circ} \mathrm{C}$ or $100{ }^{\circ} \mathrm{C}$ ) of these $m$-carborane ligands with 1,4-benzenedicarboxylic acid $\left(\mathrm{H}_{2} \mathrm{BDC}\right)$, 1,3,5-benzenetribenzoic acid $\left(\mathrm{H}_{3} \mathrm{BTB}\right)$ or 1,2,4,5-benzenetetrabenzoic acid $\left(\mathrm{H}_{4} \mathrm{TCPB}\right)$ in the presence of $\mathrm{M}\left(\mathrm{NO}_{3}\right)_{2}(\mathrm{M}=\mathrm{Co}$ and $\mathrm{Zn})$ provided crystalline CPs 1-6 in good yields and as pure phases (Scheme 2). IR spectra showed the characteristic broad B-H stretching bands from the carborane (in the range $2617 \sim 2531 \mathrm{~cm}^{-1}$ ), and the $\mathrm{C}=\mathrm{O}$ vibration of the carboxylate groups and the DMF solvent molecules (Figure S3). Crystal structures of these CPs were determined by SCXRD, and their simulated powder X-ray diffraction (PXRD) patterns compared with their experimental ones, confirming their phase purity (Figures S4-S9). SEM and optical images of these CPs also showed the formation of homogeneous crystalline samples (Figure S10). TGA data for 1-6 (Figures S11-S16) showed a first weight loss (13-29\%) in the range of $95-350{ }^{\circ} \mathrm{C}$, which corresponds to the release of solvent molecules (see ESI for details), followed by their decomposition starting at 350 ${ }^{\circ} \mathrm{C}$. Gas sorption measurements showed that all these CPs are non-porous to gases.

Crystal Structures. Suitable crystals for SCXRD were obtained for 1 and 3-6. 2 was identified by indexing the as-synthesized XRPD patterns resulting in lattice constants similar to that for $\mathbf{1}$ (Table 1). 1 crystallized in the monoclinic space group $C 2 / c$, whereas 3 crystallized in the monoclinic $P n$ space group. 4-5 crystallized in the triclinic $P-1$ space group, and 6 in the monoclinic $P 2{ }_{1} / c$ one.

$\left[\mathrm{Co}_{3}(\mathrm{BDC})_{3}(\mathrm{L1})(\mathrm{DMF})_{2}\right] \cdot 2 \mathrm{DMF}(\mathrm{1})$ and $\left[\mathrm{Co}_{3}(\mathrm{BDC})_{3}(\mathrm{L2})(\mathrm{DMF})_{2}\right] \cdot 3 \mathrm{DMF} \cdot 6 \mathrm{H}_{2} \mathrm{O}$ (2). 1 and 2 are two closely related isomorphous CPs. Single crystal analysis of $\mathbf{1}$ revealed the formation of a 3D framework based on pinwheel $\left[\mathrm{Co}_{3}(\mathrm{COO})_{6} \mathrm{O}_{2} \mathrm{~N}_{2}\right]$ units (Figure 1a). These units, which have also been observed in other related MOFs, ${ }^{41}$ are linear trinuclear cobalt cluster in which the central $\mathrm{Co}(2)$ atom resides at a crystallographic inversion center and adopts an octahedral geometry $\left\{\mathrm{O}_{6}\right\}$ coordinated to six neighboring BDC ligands (Figure 1a). Both symmetry related terminal $\mathrm{Co}(1)$ atoms are $\left\{\mathrm{NO}_{5}\right\}$-octahedrally coordinated to one $\mathbf{L 1}$ ligand, to four $\mathrm{O}$ atoms of three BDC ligands and to one $\mathrm{O}$ atom of one DMF molecule. As shown in Figure 1a, BDC ligands adopt two distinct coordination modes: the bridge bidentate $\mu-\kappa \mathrm{O}: \kappa \mathrm{O}^{\prime}$ and the bridge bidentate chelate $\mu-\kappa^{2} \mathrm{O}, \mathrm{O}^{\prime}: \kappa \mathrm{O}^{\prime}$ 
modes. $^{41}$ In this structure, each trinuclear Co(II) cluster is connected to six BDC units forming layers extended in the $b c$ plane (Figure 1c). These layers are then linked by the pillaring L1 ligand with a N-N distance of $12.15 \AA$ along the $a$ axis (Figure $1 \mathrm{~b}, \mathrm{~d}$ ), giving rise to a compact 3D structure (total solvent-accessible volume accounts for $\sim 2.9 \%$ of the unit cell volume, as estimated by Platon). ${ }^{42}$ The hydroxyl groups of the $\mathbf{L 1}$ ligand establish $\mathrm{O}-\mathrm{H} \cdots \mathrm{O}$ hydrogen bonds with the crystallized DMF molecules $\left(\mathrm{H}^{\cdots} \mathrm{O}, 1.763 \AA\right.$ A $\left.\mathrm{OHO}, 161.8^{\circ}\right)$. Since $\mathbf{1}$ and 2 are isomorphous, the unit cell parameters of $\mathbf{2}$ could be determined by PXRD-indexing of as-synthesized $\mathbf{2}$, showing a $3.36 \AA$ of enhancement in the $a$ parameter. This increase can be associated with the higher N-N distance in L2, which connects the 2D-layers along the $a$ axis (Figure 1d, Table 1).

a

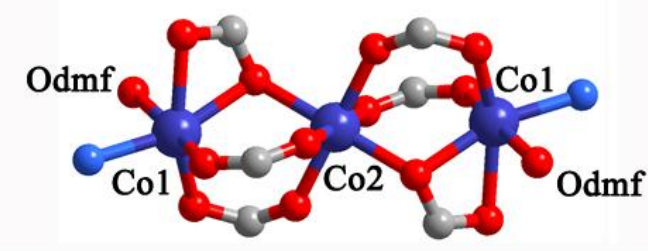

C

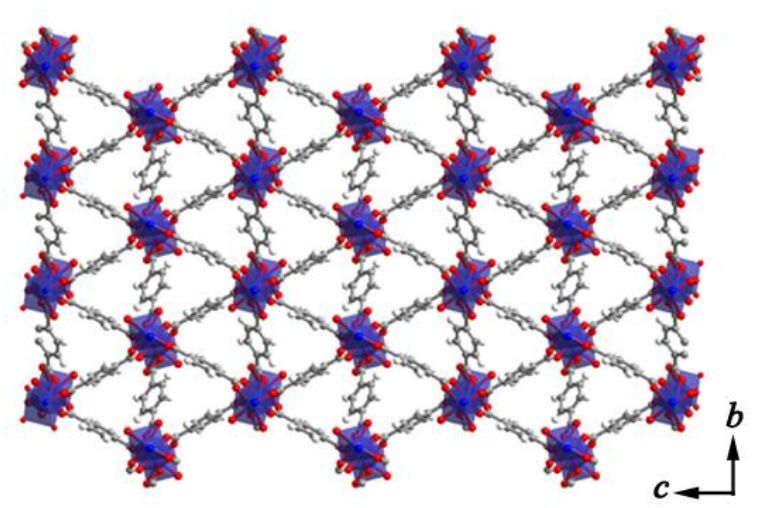

b

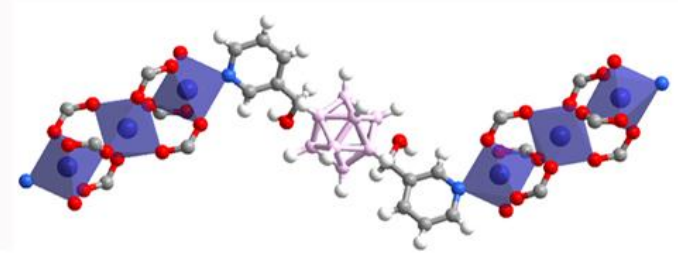

d

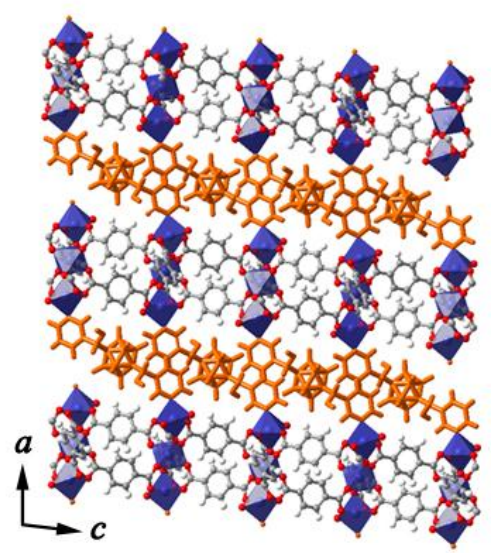

Figure 1. Crystal structure of 1: a) view of the trinuclear Co(II) cluster and coordination environment of the $\mathrm{Co}(\mathrm{II})$ centers; b) view of two trinuclear $\mathrm{Co}(\mathrm{II})$ cluster units interlinked by a $\mathbf{L 1}$ ligand; c) 2D $\left\{\mathrm{Co}_{3}-\mathrm{BDC}\right\}$ layers; and d) 3D pillared structure (L1 in orange). Coordinated DMF molecules are omitted for clarity.

$\left.\left[\mathrm{Zn}_{4}(\mathrm{BTB})_{2}(\mathrm{L2})(\mathrm{OH})_{2}\right)\left(\mathrm{H}_{2} \mathrm{O}\right)_{2}\right] \cdot 5 \mathrm{H}_{2} \mathrm{O} \cdot 4 \mathrm{DMF}(3)$. The fundamental building unit of $\mathbf{3}$ are tetranuclear $\left(\left[\mathrm{Zn}_{4} \mathrm{O}_{2}(\mathrm{COO})_{6} \mathrm{~N}_{2}\right]\right.$ clusters, in which the four $\mathrm{Zn}(\mathrm{II})$ ions are connected through six BTB and two L2 ligands (Figure 2a). $\mathrm{Zn}(1)$ and $\mathrm{Zn}(2)$ are hexacoordinated with $\left\{\mathrm{O}_{6}\right\}$ and $\left\{\mathrm{NO}_{5}\right\}$ environments, respectively. $\mathrm{Zn}(1)$ is coordinated to four $\mathrm{O}$ atoms of three different $\mathrm{BTB}$ ligands and to two $\mathrm{O}$ atoms of two $\mathrm{OH}$ groups. $\mathrm{Zn}(2)$ is coordinated to one $\mathbf{L 2}$ ligand, to three $\mathrm{O}$ atoms of three BTB ligands, to one $\mathrm{OH}$ group and to one water molecule. $\mathrm{Zn}(3)$ and $\mathrm{Zn}(4)$ are $\left\{\mathrm{NO}_{3}\right\}-$ and $\left\{\mathrm{O}_{4}\right\}$ tetracoordinated. These metal centers are coordinated to two $\mathrm{O}$ atoms of two BTB ligands, to one 
$\mathrm{OH}$ group and to one $\mathbf{L 2}$ ligand for $\mathrm{Zn}$ (3) or to one water molecule for $\mathrm{Zn}(4)$. The BTB ligands exhibit three different coordination modes: monodentate $(\kappa \mathrm{O})$, bridge bidentate $\left(\mu-\kappa \mathrm{O}^{\circ} \kappa \mathrm{O}^{\prime}\right)$ and bridge bidentate chelate $\left(\mu-\kappa^{2} \mathrm{O}, \mathrm{O}^{\prime}: \kappa \mathrm{O}^{\prime}\right)$ modes. In $\mathbf{3}$, the connection of the tetranuclear $\mathrm{Zn}(\mathrm{II})$ units through the BTB linkers creates a 3D honeycomb-like network (Figure 2c). In this network, L2 ligands bridge two tetranuclear $\mathrm{Zn}(\mathrm{II})$ units with a N-N distance of $12.20 \AA$, creating zig-zag chains that run along the $a c$ plane (Figure 2d). Overall, this framework exhibits 1D-channels running along the $b$ axis, which are occupied by highly disordered DMF molecules that were masked by Olex $2{ }^{43}$ The total solvent-accessible volume of $\mathbf{3}$ accounts for approximately $33.3 \%$ of the whole crystal volume, as estimated by PLATON. ${ }^{42}$ Hydroxyl groups of the carborane moiety are pointing to the interior of the honeycomb pores, and they are likely establishing $\mathrm{H}$-bonds with the squeezed solvent molecules.

a

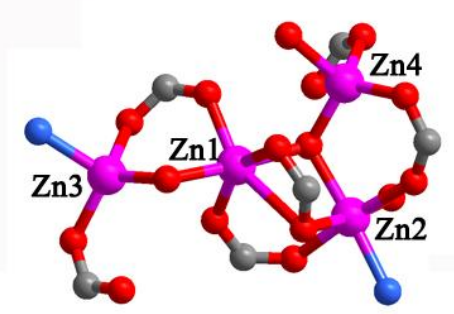

C

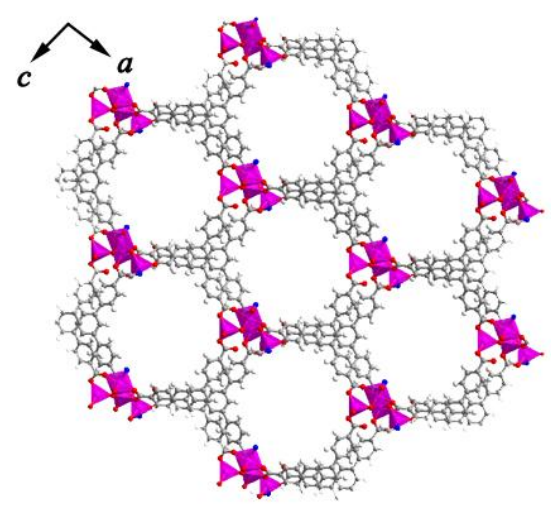

b

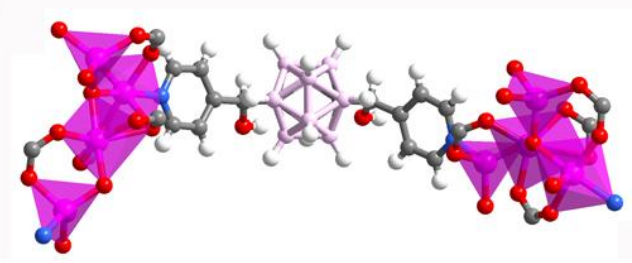

d

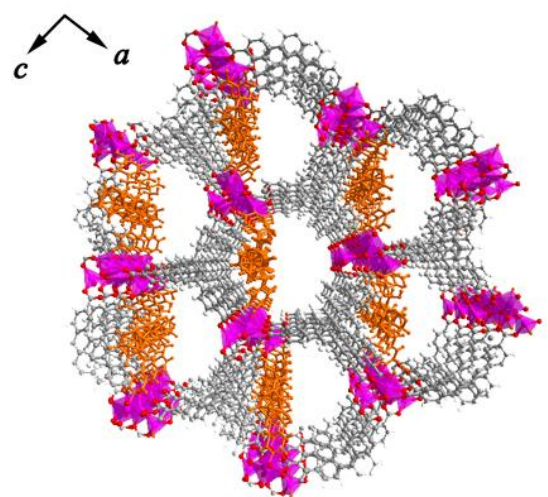

Figure 2. Crystal structure of 3: a) view of the tetranuclear $\mathrm{Zn}(\mathrm{II})$ unit and coordination environment of the $\mathrm{Zn}$ (II) metal centers; b) view of two tetranuclear $\mathrm{Zn}$ (II) units interlinked by a L2 ligand; and c-d) 3Dhoneycomb net ( $\mathbf{L} \mathbf{2}$ is omitted in c and is represented in orange in $\mathrm{d}$ ).

$\left[\mathrm{Co}_{3}(\mathrm{BTB})_{2}(\mathrm{L2})_{2}\right] \cdot 4 \mathrm{DMF}(\mathbf{4})$. As shown in Figure $3 \mathrm{a}$, the basic building unit of 4 consists of a trinuclear $\left[\mathrm{Co}_{3}(\mathrm{COO})_{6} \mathrm{~N}_{4}\right]$ unit. This unit is similar to that found in 1, except that the terminal DMF molecules are here exchanged by two L2 ligands. Each BTB ligand adopts the bridge bidentate $(\mu-$ $\left.\kappa \mathrm{O}: \kappa \mathrm{O}^{\prime}\right)$ and the bridge bidentate chelate $\left(\mu-\kappa^{2} \mathrm{O}, \mathrm{O}^{\prime}: \kappa \mathrm{O}^{\prime}\right)$ coordination modes, connecting a total of six Co(II) centers. In 4, each trinuclear Co(II) unit is coordinated to six different BTB ligands, thus creating six-pointed star fashion layers running along the $b c$ plane (Figure $3 \mathrm{~b}$ ). Then, these layers 
are pillared by $\mathbf{L} 2$ ligands resulting in a 3D framework that exhibits $1 \mathrm{D}$ channels along the $b$ axis (Figure 3d). These channels are occupied by highly disordered DMF molecules that were masked by Olex $2{ }^{43}$ The total solvent-accessible volume in the channels account for approximately $35.7 \%$ of the whole crystal volume, as estimated by PLATON. ${ }^{42}$ Once again, the flexibility of these carborane ligands was evident as the association of layers is carried out by two carborane ligands that adopt an almost L-shape (Figure 3c).
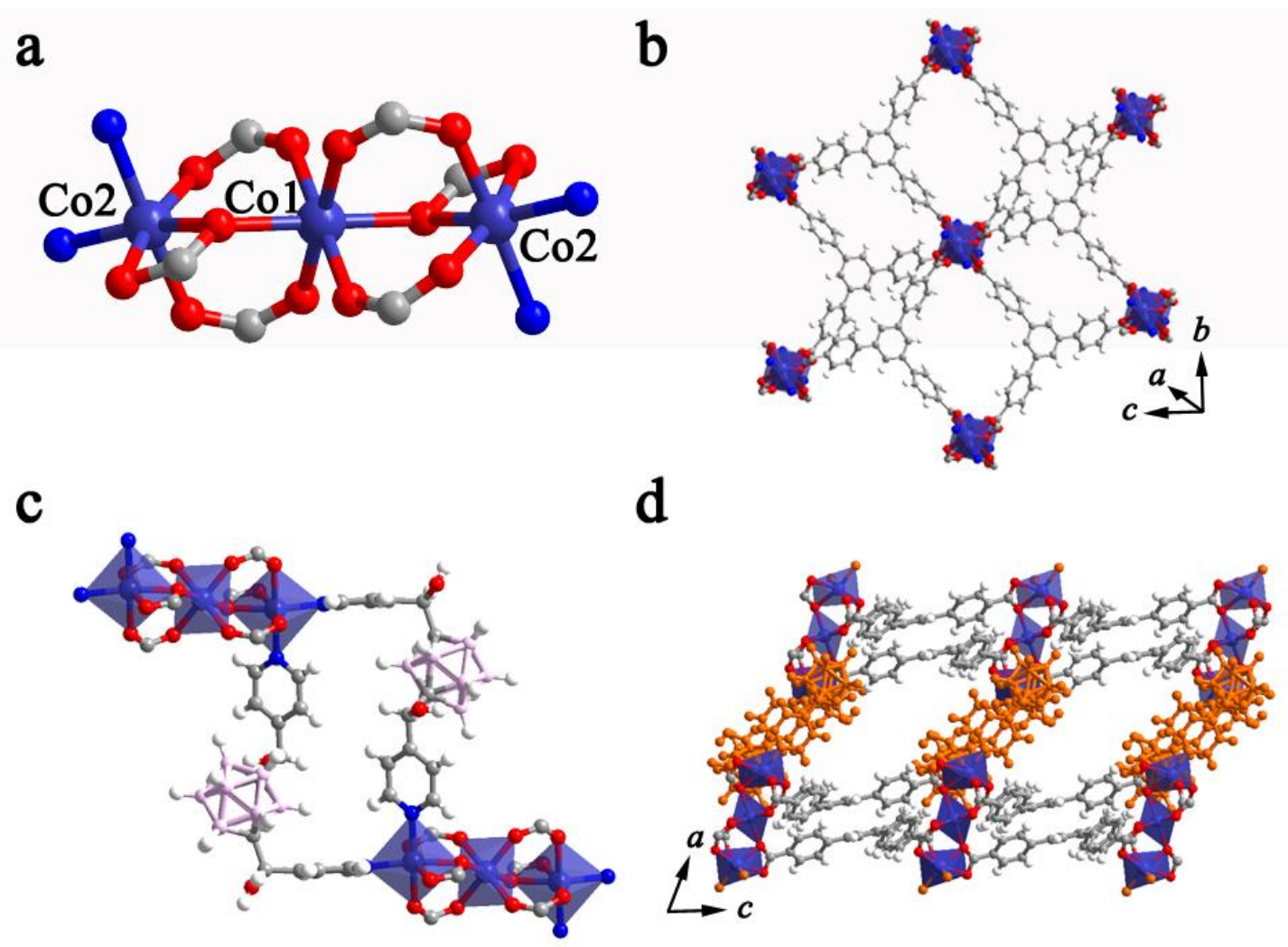

Figure 3. Crystal structure of 4: a) view of the trinuclear Co(II) unit and coordination environment of the Co(II) ions; b) six-pointed star fashion layer; c) view of two trinuclear Co(II) units interlinked by two $\mathbf{L 2}$ ligand adopting a L-shape; and d) 3D pillaring framework ( $\mathbf{L 2}$ is represented in orange).

$\left[\mathrm{Zn}_{2}(T C P B)(L 2)\right] \cdot 8 D M F(5)$. The building unit of 5 is a paddle-wheel $\left[\mathrm{Zn}_{2}(\mathrm{COO})_{4} \mathrm{~N}_{2}\right]$ cluster (Figure $4 \mathrm{a}$ ). In this unit, the $\mathrm{Zn}$ (II) ions are $\left\{\mathrm{NO}_{4}\right\}$-pentacoordinated. The values of the Addison parameter $\tau^{44}$ indicates that both $\mathrm{Zn}$ (II) centers adopt a square pyramidal geometry $(0.054$ for $\mathrm{Zn} 1$ and 0.059 for $\mathrm{Zn} 2$ ) coordinated to four $\mathrm{O}$ atoms of four different TCPB linkers occupying the basal position and to one $\mathrm{N}$ atom of the $\mathbf{L} \mathbf{2}$ in the apex position with a $\mathrm{Zn}-\mathrm{N}$ distance of 2.030(4) $\AA$. In this structure, each TCPB ligand is fully deprotonated and coordinates four paddle-wheel units in a bridge bidentate mode ( $\left.\mu-\kappa \mathrm{O}: \kappa \mathrm{O}^{\prime}\right)$, creating $2 \mathrm{D}$ layers in the $a b$ plane (Figure $4 \mathrm{~b}$ ). These layers are further pillared by $\mathbf{L} 2$ linkers with a N-N distance of $12.04 \AA$ (Figure 4c), resulting in a 3D 2-fold interpenetrated framework (Figure $4 \mathrm{~d}) .{ }^{45}$ 
a

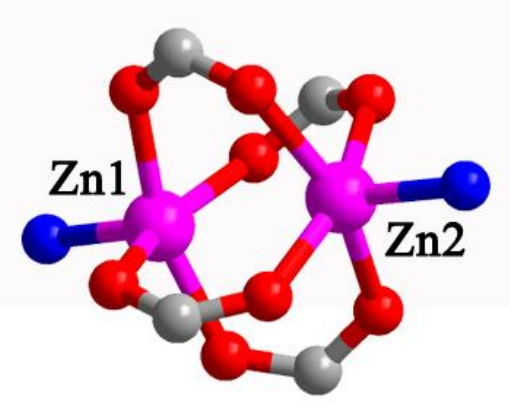

C

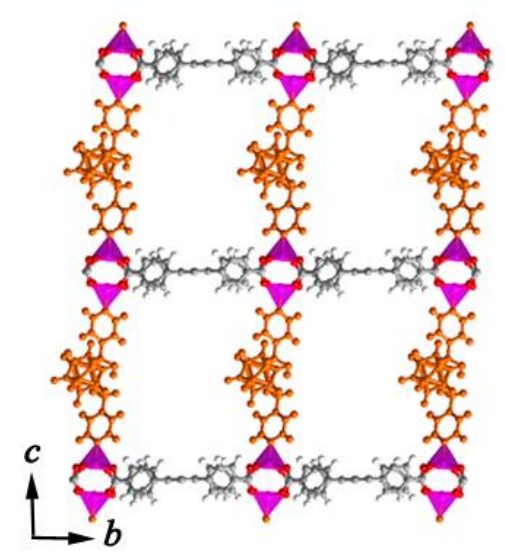

b

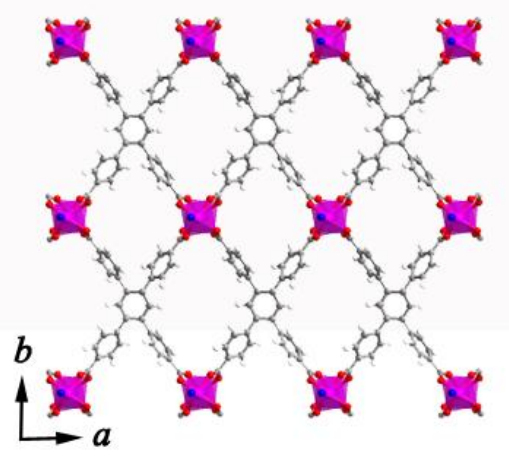

d

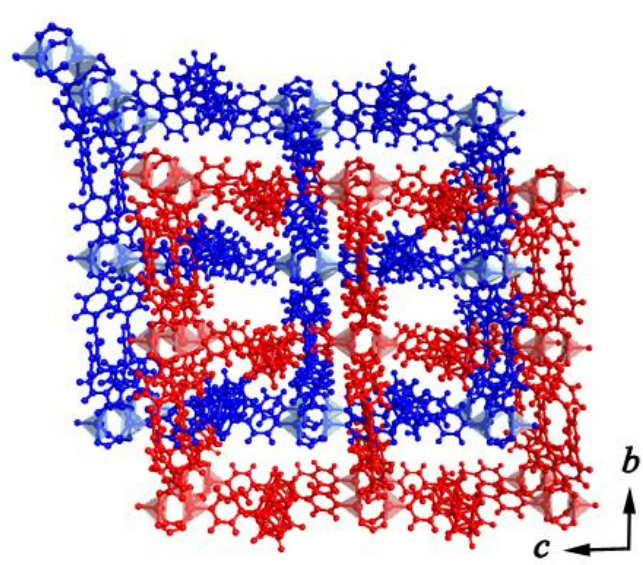

Figure 4. Crystal structure of 5: a) view of the $\mathrm{Zn}(\mathrm{II})$ paddle-wheel unit; b) 2D layer; c) 3D pillaring structure (L2 is represented in orange); and d) two-fold interpenetrated framework, highlighting each one of the pillaring structures in red and blue.

$\left[\mathrm{Co}_{2}(\mathrm{TCPB})(\mathrm{L2})\left(\mathrm{H}_{2} \mathrm{O}\right)\left(\mu-\mathrm{H}_{2} \mathrm{O}\right)(\mathrm{DMF})\right] \cdot 2.7 \mathrm{DMF}(\mathbf{6})$. As shown in Figure 5a, the building unit of 6 is a dinuclear $\left[\mathrm{Co}_{2}(\mathrm{COO})_{4} \mathrm{~N}_{2}\right]$ cluster, in which both $\mathrm{Co}(\mathrm{II})$ centers are $\left\{\mathrm{NO}_{5}\right\}$-hexacoordinated. $\mathrm{Co}(1)$ is coordinated to two $\mathrm{O}$ atoms from two TCPB ligands, to one DMF molecule, to one bridge and one terminal water molecule and to one $\mathbf{N}$ atom from one $\mathbf{L} 2$ linker, whereas $\mathrm{Co}(2)$ is coordinated to four $\mathrm{O}$ atoms from four different TCPB ligands, to the bridge water molecule and to the $\mathrm{N}$ atom of one $\mathbf{L 2}$ linker. The TCPB ligands coordinate the dinuclear Co(II) units in a bridge bidentate $\left(\mu-\kappa \mathrm{O}: \kappa \mathrm{O}^{\prime}\right)$ and a monodentate $(\kappa \mathrm{O})$ coordination mode (Figure $\left.5 \mathrm{~b}\right)$. The structure of 6 consists on bidimensional square grid layers built up from connecting each dinuclear Co(II) unit to four TCPB ligands and each TCPB ligand to four Co(II) units (Figure 5b). In this structure, $\mathbf{L} 2$ ligands are not involved in increasing the structural dimensionality of 6. Instead, the U-shape orientation of $\mathbf{L} \mathbf{2}$ bridges two $\mathrm{Co}$ (II) atoms of the same layer with a Co-Co distance of $\sim 11 \AA$ (Figure 5b,c). These layers are packed through several O-H $\cdots \mathrm{O}$ H-bonds involving the coordinated water molecule and the $\mathrm{O}$ atom of a carboxylate group (Figure 5d). 
a

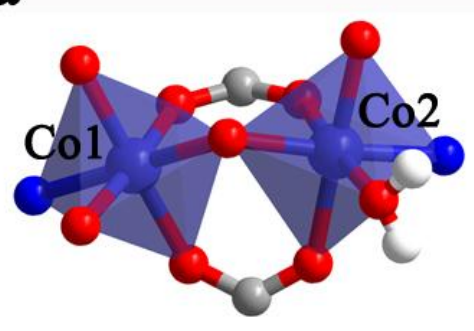

c

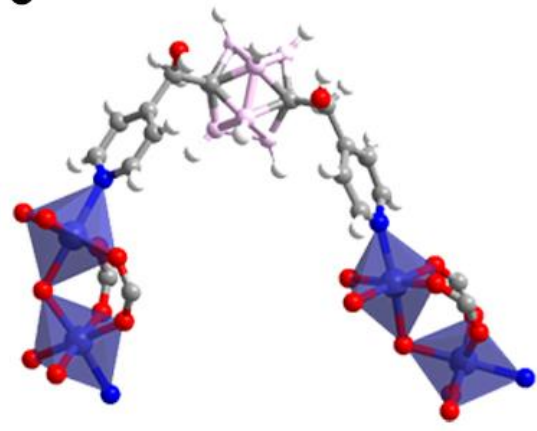

b

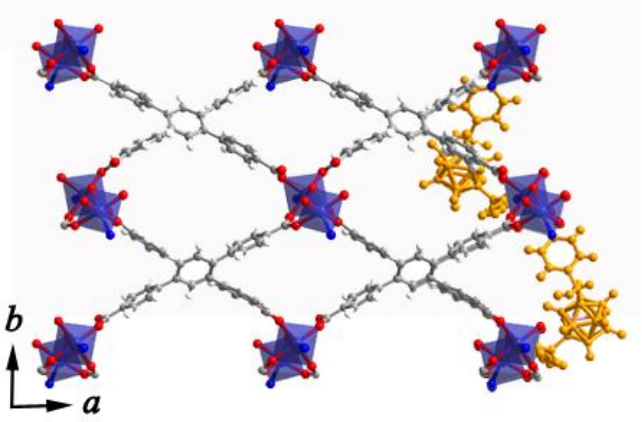

d

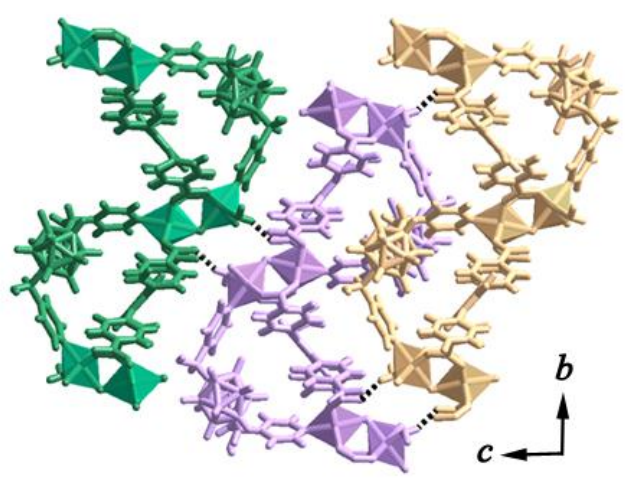

Figure 5. Crystal structure of 6: a) view of the dinuclear $\mathrm{Co}(\mathrm{II})$ unit; b) square grid layer extended along the $a b$ plane (L2 connecting two Co(II) centers in the same layer is represented in orange); c) view of two dinuclear $\mathrm{Co}$ (II) units bridged through one L2 ligand; and d) 3D packing of the coordination layers through $\mathrm{Ow}-\mathrm{H} \cdots \mathrm{O}$ H-bond interactions (represented as black dotted lines).

The flexibility of both $\mathbf{L} \mathbf{1}$ and $\mathbf{L} \mathbf{2}$ ligands is reflected in the variety of generated structures (Figures 1-5 and Figure S2). Overall, these carborane-based ligands can have two major roles in the CP structures: (i) act as pillars, being involved in the dimensionality of the final CP structure; and (ii) act as decorative ligands in order to complete the coordination sphere of the metal centers. In either case, it is known that introducing hydrophobicity on the internal surface of the structure and/or sterics around the metals can increase the hydrolytic stability of the coordination structure. ${ }^{46}$, ${ }^{47}$ In our case, the use of the hydrophobic carborane-based L1 and L2 ligands may increase the water stability of the related CPs. To study this water stability, the different CPs were immersed in liquid $\mathrm{H}_{2} \mathrm{O}$ overnight at room temperature. Analysis of the recovered crystalline solids by PXRD revealed that only $\mathbf{3}$ and $\mathbf{4}$ retained their structure after this incubation time, as no change in their PXRD patterns were observed (Figures S17). We are currently investigating whether the proximity of the $m \mathrm{CB}$ cages to the metals could be responsible for the different hydrolytic stability of $\mathbf{3}$ and $\mathbf{4}$. 
Guest Encapsulation of 4. Motivated by the relatively large solvent accessible volume of 4 ( $36 \%)$ and the large size and morphology of the crystals (Figure S10d), we decided to study whether this $\mathrm{CP}$ could act as a crystalline sponge for guest molecules and whether some specific host-guest interactions could be observed. ${ }^{6,7}$ As mentioned above, the as-prepared 4 contains DMF molecules as guest; so, hereafter it will be named as $4 \supset$ DMF. To study its guest-exchange capabilities, the as-prepared crystals of $\mathbf{4}$ DMF were immersed in an excess of several selected organic solvents for 24-48 h, and the exchange was monitored by IR-ATR following the changes in the $\mathrm{C}=\mathrm{O}$ stretching band of DMF. Remarkably, complete post-synthetic exchange of DMF guest molecules was achieved in methanol, chloroform, benzene, toluene, nitrobenzene and 1-nitropropane, but no significant exchange was observed for cyclohexane, hexane and carbon tetrachloride. The different nature of the solvents that replaced the DMF in $4 \supset$ DMF prompted us to study more in detail the sponge behavior of this particular CP. Structural characterization using SCXRD showed that guest exchange processes resulted in 6 new structures, including د $4 \mathbf{M e O H}$ (methanol), 4 つ $\mathbf{C H C l}_{3}$ (chloroform), 4 DP (1-nitropropane), $4 \supset \mathbf{~ N B z}$ (nitrobenzene), $4 \supset \mathbf{B z}$ (benzene) and $4 \supset$ Tol (toluene). Crystal and data collection details can be found in Table S1 (ESI). All guest-containing structures $4 \supset$ Guest were found to crystallize in the same centrosymmetric space group $P$-1, showing an expansion $(\mathrm{Bz}<\mathrm{NP}<\mathrm{Tol}<\mathrm{NBz})$, a contraction $(\mathrm{MeOH})$ and almost no change $\left(\mathrm{CHCl}_{3}\right)$ of the unit cell parameters when compared with the as-prepared $4 \supset$ DMF. The higher expansion of the unit cell was found in $\mathbf{4} \supset \mathbf{N B z}$ and $\mathbf{4}$ د Tol with a volume increase of $140 \AA^{3}$ and $71 \AA^{3}$, respectively. DMF and MeOH molecules in $\mathbf{4} \supset$ Guest structures were highly disordered, so that the solvent masking procedure implemented in Olex $2^{43}$ was used to remove the electronic contribution of solvent molecules from the refinement. $\mathrm{CHCl}_{3}$ and $\mathrm{NP}$ were partially masked, but aromatic solvents (benzene, toluene and nitrobenzene) were clearly located and refined (Table S1 and Figure 6). 
a

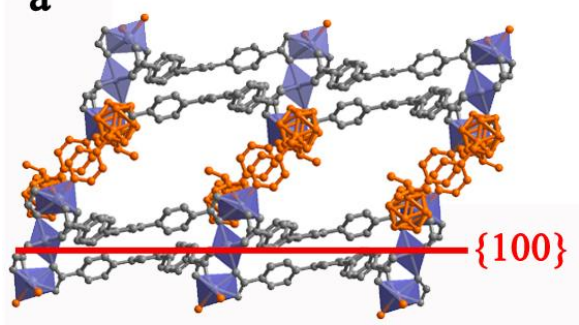

b

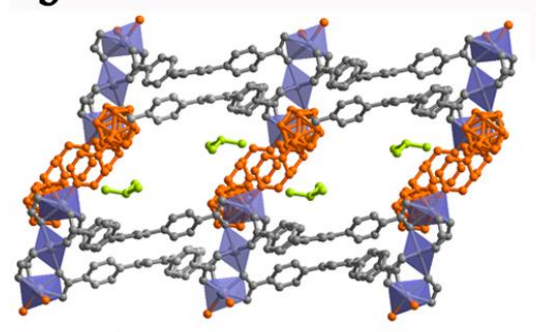

c

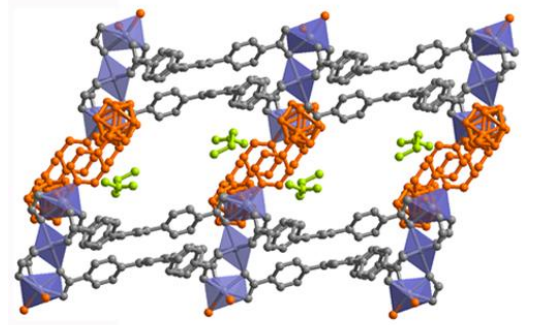

d

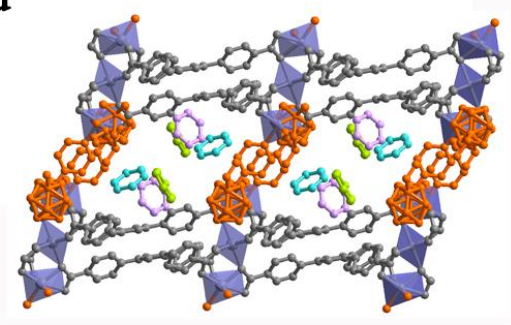

e

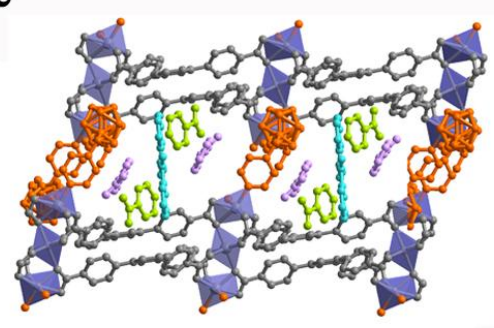

f

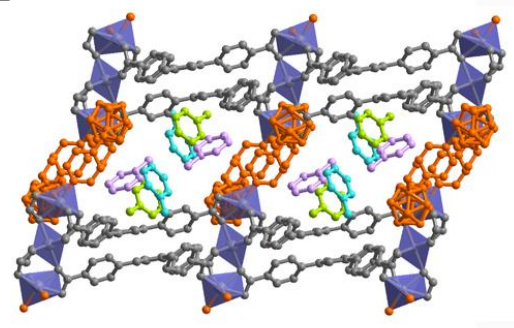

Figure 6. Plots of the X-ray crystal structures for $4 \supset$ Guest, viewed along the $b$ axis: a) DMF, b) chloroform, c) 1-nitropropane, d) benzene, e) nitrobenzene and f) toluene. Guest molecules are shown with colors corresponding to equivalent sites. The framework is shown in grey, except for $\mathbf{L 2}$, that are represented in orange. $\mathrm{H}$ atoms are omitted for clarity. The plane orthogonal to the $\mathbf{L 2}$ linkers $\{100\}$ is highlighted in red.

The possibility to solve the X-ray crystal structure of the different $4 \supset$ Guest (Figure 6) allowed us to further analyze the nature of the host-guest interactions (Tables 2-3 and Figures S18S22). In the case of $\mathbf{4} \supset \mathbf{C H C l}_{\mathbf{3}}$ and $\mathbf{4} \supset \mathbf{N P r}$, one guest molecule was found in the asymmetric unit (Figures $7 \mathrm{~b}-\mathrm{c}$ ). Here, whereas the nonpolar $\mathrm{CHCl}_{3}$ molecule interacts with the aromatic rings of the BTB molecules by $\mathrm{C}-\mathrm{H}^{\cdots} \pi$ interactions, the polar aprotic NP mainly establishes H-bond interactions with the $\mathrm{OH}$ groups of $\mathbf{L 2}$. For $\mathbf{4} \supset \mathbf{N B z}, \mathbf{4} \supset \mathbf{B z}$ and $4 \supset$ Tol, it was possible to precisely refine all aromatic guest molecules inside the framework (Figure 6d-f), probably due to the large number of host-guest interactions present in these solvates/structures (Tables 2-3 and Figures S20-S22). Hydroxyl groups of $\mathbf{L 2}$ establish classical H-bond interactions with $\mathrm{NBz}$ molecules in $\mathbf{4}$ د NBz (Figure S20a), whereas O-H $\cdots \pi$ interactions are observed in $\mathbf{4} \supset \mathbf{B z}$ and 4 Tol (Figures S20, S22). The aromatic nature of these guest molecules allows establishing $\mathrm{C}-\mathrm{H} \cdots \pi$ 
and $\pi \cdots \pi$ interactions with either BTB or L2 linkers. Interestingly, the carborane core also participates in host-guest interactions via weak $\mathrm{C}-\mathrm{H} \cdots \mathrm{H}-\mathrm{B}$ interactions, as observed in $\mathbf{4} \supset \mathbf{B z}$ and 4 ๖ Tol. $^{48-50}$

Table 2. Geometrical parameters of host-guest contacts $\left(\AA{ }^{\circ}{ }^{\circ}\right)$, involved in $\mathbf{4} \supset$ Guest structures. For $\mathrm{C}-\mathrm{H} \cdots \pi$ contacts, geometries are given with respect to the aromatic centroid $\mathrm{M}^{\left[{ }^{[a]}\right.}$

\begin{tabular}{|c|c|c|c|c|}
\hline Guest & $\mathrm{D}-\mathrm{H} \cdots \mathrm{A}^{[\mathrm{b}]}$ & $d(\mathrm{H} \cdots \mathrm{A})$ & $<$ (DHA) & $<(\mathrm{HHB})$ \\
\hline \multirow{4}{*}{$\mathrm{CHCl}_{3}$} & Host-Guest & & & \\
\hline & $\left(\mathrm{CHCl}_{3}\right) \mathrm{C}(62)-\mathrm{H} \cdots \mathrm{M}$ & 2.367 & 171.86 & - \\
\hline & Guest-Guest & & & \\
\hline & - & - & - & - \\
\hline \multirow{6}{*}{ NPr } & Host-Guest & & & \\
\hline & $($ L2) $\mathrm{O}(22 \mathrm{~B})-\mathrm{H} \cdots \mathrm{O}(62)$ & 2.451 & 156.0 & - \\
\hline & $(\mathbf{L 2}) \mathrm{O}(22 \mathrm{~B})-\mathrm{H} \cdots \mathrm{O}(64)$ & 1.809 & 125.8 & - \\
\hline & $(\mathrm{NPr}) \mathrm{C}(65)-\mathrm{H}(\mathrm{A}) \cdots \mathrm{M}$ & 2.476 & 143.3 & - \\
\hline & Guest-Guest & & & \\
\hline & - & - & - & - \\
\hline \multirow{9}{*}{$\mathbf{N B z}$} & Host-Guest & & & \\
\hline & $(\mathbf{L 2}) \mathrm{O}(22 \mathrm{~A})-\mathrm{H} \cdots \mathrm{O}(82)$ & 2.368 & 143.9 & - \\
\hline & (L2) $\mathrm{C}(19)-\mathrm{H} \cdots \mathrm{O}(92)$ & 2.651 & 122.4 & - \\
\hline & $(\mathbf{L 2}) \mathrm{C}(20)-\mathrm{H} \cdots \mathrm{O}(92)$ & 2.577 & 124.4 & - \\
\hline & $(\mathrm{BTB}) \mathrm{C}(54)-\mathrm{H} \cdots \mathrm{O}(93)^{\mathrm{i}}$ & 2.633 & 160.6 & - \\
\hline & (L2) $\mathrm{C}(17)-\mathrm{H} \cdots \mathrm{M}$ & 2.820 & 145.3 & - \\
\hline & $(\mathrm{NBz}) \mathrm{C}(99)-\mathrm{H} \cdots \mathrm{M}$ & 2.660 & 153.6 & - \\
\hline & Guest-Guest & & & \\
\hline & $\mathrm{C}(97)-\mathrm{H} \cdots \mathrm{O}(72)$ & 2.483 & 132.9 & - \\
\hline \multirow{9}{*}{$\mathbf{B z}$} & $\underline{\text { Host-Guest }}$ & & & \\
\hline & $(\mathbf{L 2}) \mathrm{O}(01 \mathrm{M})-\mathrm{H} \cdots \mathrm{C}(95)$ & 2.648 & 165.3 & - \\
\hline & $(\mathbf{L 2}) \mathrm{O}(01 \mathrm{M})-\mathrm{H} \cdots \mathrm{C}(90)$ & 2.702 & 150.6 & - \\
\hline & (BTB) $\mathrm{C}(45)-\mathrm{H} \cdots \mathrm{C}(90)$ & 2.640 & 159.5 & - \\
\hline & (BTB) $\mathrm{C}(43)-\mathrm{H} \cdots \mathrm{M}$ & 2.943 & 139.8 & - \\
\hline & $(\mathrm{Bz}) \mathrm{C}(82)-\mathrm{H} \cdots \mathrm{M}^{\mathrm{i}}$ & 2.704 & 155.2 & - \\
\hline & $(\mathrm{Bz}) \mathrm{C}(80)-\mathrm{H} \cdots \mathrm{H}-\mathrm{B}(2)$ & 2.246 & 130.4 & 157.7 \\
\hline & Guest-Guest & & & \\
\hline & $\mathrm{C}(96)-\mathrm{H} \cdots \mathrm{M}$ & 2.969 & 121.0 & - \\
\hline \multirow{7}{*}{ Tol } & $\underline{\text { Host-Guest }}$ & & & \\
\hline & $(\mathbf{L 2}) \mathrm{O}(022 \mathrm{~A})-\mathrm{H} \cdots \mathrm{C}(84)$ & 2.648 & 154.7 & - \\
\hline & $(\mathbf{L 2}) \mathrm{O}(022 \mathrm{~A})-\mathrm{H} \cdots \mathrm{C}(85)$ & 2.654 & 156.1 & - \\
\hline & (Tol) $\mathrm{C}(73)-\mathrm{H} \cdots \mathrm{M}$ & 2.692 & 147.6 & - \\
\hline & $(\mathrm{Tol}) \mathrm{C}(71 \mathrm{~A})-\mathrm{H} \cdots \mathrm{H}-\mathrm{C}(37)$ & 2.313 & 129.4 & 131.3 \\
\hline & Guest-Guest & & & \\
\hline & $\mathrm{C}(71 \mathrm{~B})-\mathrm{H} \cdots \mathrm{M}$ & 2.949 & 130.0 & \\
\hline
\end{tabular}

[a] See Figures S17-S21 in ESI for XRD representations of the contacts. [b] O-H bond lengths are not normalised to neutron distances. Symmetry codes (i) -x,1-y,1-z. 
Table 3. Arene-arene packing geometries $\left(\AA,{ }^{\circ}\right)$, involved in $4 \supset \mathbf{B z}$ and $\mathbf{4} \supset$ Tol. ${ }^{[\mathrm{a}]}$

\begin{tabular}{|c|c|c|c|c|c|}
\hline \multirow{2}{*}{\multicolumn{6}{|c|}{ Interplanar }} \\
\hline & & & & & \\
\hline Guest & distance & angle & $d^{[b]}$ & $\mathbf{H d}^{[\mathrm{b}]}$ & $\theta^{[\mathrm{c}]}$ \\
\hline \multirow{2}{*}{ Bz } & $3.396^{[\mathrm{d}]}$ & 11.39 & 3.890 & 1.897 & 29.2 \\
\hline & $3.082^{[\mathrm{e}]}$ & 22.53 & 3.988 & 2.531 & 39.4 \\
\hline Tol & $3.397^{[\mathrm{f}]}$ & 10.11 & 3.848 & 1.808 & 28.0 \\
\hline
\end{tabular}

[a] See embedded Chart at the top for nomenclature and Figures S19 and S21 in ESI. [b] Ring centroid to ring centroid distance. [c] Ring normal to vector between the ring centroids. [d] Shortest carbon-carbon distance (C24-C92). [e] Shortest carbon-carbon distance (C36-C98). [f] Shortest carbon-carbon distance (C24-C82).

Nanomechanical Properties of $4 \supset$ Guest. Mechanical tunability of CP/MOFs as a result of strong host-guest interactions represents nowadays a challenging approach for the development of novel applications. ${ }^{10,11}$ The mechanical properties of a number of CP/MOFs, such as MOF-5, ${ }^{51}$ ${ }^{52} \mathrm{ZIFs}^{53}$ and soft porous crystals of the type $\left[\mathrm{Zn}_{2}\left(\mathrm{~L}_{2}\right)(\text { dabco })\right]_{\mathrm{n}}(\mathrm{L}=1$,4-benzenedicarboxylate derivatives, dabco = 1,4-diazabicyclo[2.2.2] octane), have been investigated experimentally. ${ }^{54}$ The latter is an interesting example that is closely related to our findings. It was found that the mechanical properties of $\left[\mathrm{Zn}_{2}\left(\mathrm{~L}_{2}\right)(\mathrm{dabco})\right]_{\mathrm{n}}$ are primarily dependent on the detailed network geometry and the precise orientation of the molecular building blocks within the porous framework, but not to specific guest-framework interactions. However, in this study, the authors demonstrated that guest molecules influence the framework geometry (e.g. tilt angle and bending of linkers) of this family of CPs and therefore, their mechanical properties. On another study, effects of pore occupancy on elasticity were proved on ZIF-8 single-crystals, where a decrease $(\sim 7 \%)$ in elasticity (E) was observed on desolvation. ${ }^{53}$

The series of guest-containing structures $\mathbf{4} \supset$ Guest in this work represents an ideal platform for studying the mechanical properties of such porous materials. Indeed, as shown in the previous section, the guest molecules affect the volume of the structures (Table 1) but not the symmetry of the framework (neither tilt angle nor bending of linkers was observed). Thus, we hypothesized that any variation on the mechanical properties for the $\mathbf{4} \supset$ Guest structures should be related to the nature of the guest molecules and/or the specific host-guest interactions.

Single-crystal nanoindentation experiments were performed under conventional quasi-static stiffness using Berkovich pyramidal-shaped diamond tip operating in the load control mode (see ESI for details). Single measurement mode using crystals of $4 \supset$ Guest (Guest $=$ DMF, $\mathrm{CHCl}_{3}$, 
$\mathrm{NPr}, \mathrm{NBz}, \mathrm{Bz}, \mathrm{Tol}$ and $\mathrm{MeOH})$ were carefully selected, and the $\{100\}$-oriented facets were oriented normal to the indenter axis. Note here that the anisotropic of the single crystals of $\mathbf{4} \supset$ Guest enabled indexing their plate face, which was identified as the $\{100\}$ plane (Figure 6a and S23). Measurements were done after taking the crystals from the appropriate solvents (within $5 \mathrm{~h}$ ) and crystallinity of the measured samples were confirmed a posteriori by PXRD and optical microscope. Solvent loss and amorphization were observed in crystals being in air for over $24 \mathrm{~h}$ in all cases, expect for $\mathrm{CHCl}_{3}$ and $\mathrm{MeOH}$ that did after $10 \mathrm{~h}$ (Figure S24). Averaged data is listed in Table 4. The nanoindentation results on $\mathbf{4}$ \Guest revealed significant variations in the Young's modulus (E) depending on the guest.

Table 4. Mechanical properties of different $4 \supset$ Guest on the $\{100\}$-oriented facets determined by nanoindentation experiments. $E$ is the elastic modulus and $H$ the hardness. All samples were measured right after taking them out of the solvents and slightly dried on a filter paper.

\begin{tabular}{lll}
\hline Guest & E/GPa & H/GPa \\
\hline $\mathrm{CHCl}_{3}$ & $0.556(36)$ & $0.078(8)$ \\
\hline Nitropropane & $1.20(13)$ & $0.203(28)$ \\
\hline MeOH & $1.367(65)$ & $0.272(18)$ \\
\hline DMF & $1.71(17)$ & $0.197(27)$ \\
\hline Toluene & $1.75(15)$ & $0.250(28)$ \\
\hline Nitrobenzene & $1.83(13)$ & $0.471(43)$ \\
\hline Benzene & $2.67(28)$ & $0.322(56)$ \\
\hline
\end{tabular}

The elastic modulus of $\mathbf{4}$ can vary for a factor or nearly 5 for the $\{100\}$ crystallographic orientation by simply exchanging the guest molecules. The average moduli $E_{\{100\}}$ are in the range between 0.6 to $2.7 \mathrm{GPa}$. These values are comparable to other porous MOFs. ${ }^{11,54}$ It is however interesting that higher elastic modulus of $\mathbf{4}$ were observed when aromatic solvent molecules or DMF were occupying the voids (1.71-2.67 GPa). On the other hand, sensibly smaller elastic modulus was observed when non aromatic polar solvent molecules (MeOH, $1.37 \mathrm{GPa}$; Nitropropane, $1.20 \mathrm{GPa})$ or the non polar $\mathrm{CHCl}_{3}(0.56 \mathrm{GPa})$ are filling the 4 pores. The hardness along the same $\{100\}$ crystallographic orientation also reveals an increase, although not as pronounced, as a function of the adsorbed guest. $H_{\{100\}}$ values are in the range between 0.20-0.47 $\mathrm{GPa}$, except that for the $\mathrm{CHCl}_{3}$ guest structure that provides a sensibly lower value $(0.08 \mathrm{GPa})$. 
As hypothesized above, any variation on the mechanical properties for our $4 \supset$ Guest structures should be related to the nature of the guest molecules and/or the specific host-guest interactions. The mechanical response of the $\{100\}$-oriented facets is mainly dominated by the L2-pillars, which interconnect the 2D \{Co-BTB $\}$ layers (Figures 3 and 6). In all $4 \supset$ Guest structures, the L2-pillars are at the same angle respect to the $\{100\}$ crystals facets, so that comparable $E$ and $H$ values should be obtained based on the networks geometries. ${ }^{54}$ This suggests that the observed specific host-guest interactions have an impact in the mechanical properties of 4 . Solvates with higher number of host-guest interactions show higher Young's moduli and higher hardness (Young's moduli is 5 times higher in $\mathbf{4} \supset \mathbf{B z}$ than in $\mathbf{4} \supset \mathbf{C H C l}_{3}$ ). In contrast, lower elastic modulus and hardness was found in $\mathbf{4} \supset \mathbf{C H C l}_{3}$, in $\mathbf{4} \supset \mathbf{N P r}$ and in $\mathbf{4} \supset \mathbf{D M F}$, where the guest molecules are highly or partially disordered, which suggests very weak or non-specific host-guess interactions are taking place in these cases. On the contrary, aromatic solvents show a high number of specific interactions with the framework of $\mathbf{4}$, and consequently, high elastic modulus and hardness values.

\section{CONCLUSIONS}

In conclusion, we have reported the synthesis and characterization of six new CPs obtained from the reaction between two novel $m$-carborane bispyridilalcohol ligands and different di-, tri- and tetracarboxylic linkers with $\mathrm{M}\left(\mathrm{NO}_{3}\right)_{2}$ salts $(\mathrm{M}=\mathrm{Zn}$ and $\mathrm{Co})$. The flexibility of the carborane moieties is reflected in the structural diversity of the generated coordination networks, showing in most of the cases their ability to increase the dimensionality of the final framework by acting as pillar ligands. Complete post-synthetic exchange of DMF guest molecules by a variety of organic solvents was achieved in one of these CPs. This CP (named as 4) acts as a crystalline sponge showing a higher affinity for aromatic guest molecules due to the presence of a large number of host-guest interactions $\left(\mathrm{O}-\mathrm{H}^{\cdots} \pi, \mathrm{C}-\mathrm{H} \cdots \pi, \pi \cdots \pi\right.$ and weak $\left.\mathrm{C}-\mathrm{H}^{\cdots} \mathrm{H}-\mathrm{B}\right)$. This high number of interactions is probably the reason to render the aromatic guest molecules regularly ordered in the X-ray structures, unlike other non-aromatic molecules. The nanoindentation experiments on 4 Guest suggest that a higher number of host-guest contacts has also an effect on the hardness and Young's moduli values, which can be five times higher (e.g. $\mathbf{4} \supset \mathbf{B z}$ versus $\mathbf{4} \supset \mathbf{C H C l}_{3}$ ). Thus, our work provides an easy route to synthesize new $m$-carborane derivatives as linkers for $\mathrm{CP}$ preparation. In this line, we are currently investigating the synthesis of other CP systems based on carborane-based N-heterocyclic bases.

\section{ACKNOWLEDGMENTS}


This work was supported by the EU FP7 ERC-Co 615954. M.Y.T., T.F., F.T., C.V. and J.G.P. thank MEC grants CTQ2013-44670-R and the Generalitat de Catalunya (2014/SGR/149) for financial support. The Intramural CSIC (201530E011) provided X-ray structural facilities for this work. I.I. thanks the MINECO for a RyC fellowship. ICMAB and ICN2 acknowledge the support of the Spanish MINECO through the Severo Ochoa Centers of Excellence Program, under Grant SEV-2015-0496 and SEV-2013-0295. F. Tang is enrolled in the UAB PhD program and acknowledges the China Scholarship Council (CSC) for her PhD grants (201506060171).

\section{SUPPORTING INFORMATION}

Spectroscopic and crystallographic data. This material is available free of charge via the internet at http://pubs.acs.org/.

\section{REFERENCES}

(1) Kitagawa, S.; Kitaura, R.; Noro, S.-i., Angew. Chem. Int. Ed. 2004, 43, 2334-2375.

(2) Lin, Z.-J.; Lu, J.; Hong, M.; Cao, R., Chem. Soc. Rev. 2014, 43, 5867-5895.

(3) James, S. L., Chem. Soc. Rev. 2003, 32, 276-288.

(4) Li, H.; Eddaoudi, M.; O'Keeffe, M.; Yaghi, O. M., Nature 1999, 402, 276-279.

(5) Haldar, R.; Maji, T. K., CrystEngComm 2013, 15, 9276-9295.

(6) Inokuma, Y.; Yoshioka, S.; Ariyoshi, J.; Arai, T.; Hitora, Y.; Takada, K.; Matsunaga, S.; Rissanen, K.; Fujita, M., Nature 2013, 495, 461-466.

(7) Hayes, L. M.; Knapp, C. E.; Nathoo, K. Y.; Press, N. J.; Tocher, D. A.; Carmalt, C. J., Cryst. Growth Des. 2016, 16, 3465-3472.

(8) Ullman, A. M.; Brown, J. W.; Foster, M. E.; Léonard, F.; Leong, K.; Stavila, V.; Allendorf, M. D., Inorg. Chem. 2016, 55, 7233-7249.

(9) Ullman, A. M.; Brown, J. W.; Foster, M. E.; Léonard, F.; Leong, K.; Stavila, V.; Allendorf, M. D., Inorg. Chem. 2016.

(10) Li, W.; Henke, S.; Cheetham, A. K., APL Materials 2014, 2.

(11) Tan, J. C.; Cheetham, A. K., Chem. Soc. Rev. 2011, 40, 1059-1080.

(12) Grimes, R. N., Carboranes (Second Edition). ed.; Academic Press: Oxford, 2011.

(13) Scholz, M.; Hey-Hawkins, E., Chem. Rev. 2011, 111, 7035-7062.

(14) Olid, D.; Núñez, R.; Viñas, C.; Teixidor, F., Chem. Soc. Rev. 2013, 42, 3318-3336.

(15) Grimes, R. N., Dalton Trans. 2015, 44, 5939-5956.

(16) Spokoyny, A. M., Pure and Applied Chemistry 2013, 85, 903-919.

(17) Teixidor, F.; Viñas, C., In Science of Synthesis, D.E., K., Ed. 2005; Vol. 6, p 1325.

(18) Tsang, M. Y.; Teixidor, F.; Viñas, C.; Choquesillo-Lazarte, D.; Aliaga-Alcalde, N.; Planas, J. G., Inorg. Chim. Acta 2016, DOI: 10.1016/j.ica.2016.04.028.

(19) Planas, J.; Teixidor, F.; Viñas, C., Crystals 2016, 6, 50.

(20) Tsang, M. Y.; Viñas, C.; Teixidor, F.; Planas, J. G.; Conde, N.; SanMartin, R.; Herrero, M. T.; Dominguez, E.; Lledos, A.; Vidossich, P.; Choquesillo-Lazarte, D., Inorg. Chem. 2014, 53, 9284-95.

(21) Di Salvo, F.; Tsang, M. Y.; Teixidor, F.; Viñas, C.; Planas, J. G.; Crassous, J.; Vanthuyne, N.; Aliaga-Alcalde, N.; Ruiz, E.; Coquerel, G.; Clevers, S.; Dupray, V.; Choquesillo-Lazarte, D.; Light, M. E.; Hursthouse, M. B., Chem. Eur. J. 2014, 20, 1081-1090. 
(22) Di Salvo, F.; Teixidor, F.; Viñas, C.; Giner Planas, J., Z. Anorg. Allg. Chem. 2013, 639, 1194-1198.

(23) Di Salvo, F.; Teixidor, F.; Viñas, C.; Giner Planas, J.; Light, M. E.; Hursthouse, M. B.; Aliaga-Alcalde, N., Crystal Growth \& Design 2012, 12, 5720-5736.

(24) Bae, Y. S.; Spokoyny, A. M.; Farha, O. K.; Snurr, R. Q.; Hupp, J. T.; Mirkin, C. A., Chem. Commun. 2010, 46, 3478-3480.

(25) Bae, Y.-S.; Farha, O. K.; Spokoyny, A. M.; Mirkin, C. A.; Hupp, J. T.; Snurr, R. Q., Chem. Commun. 2008, 4135-4137.

(26) Clingerman, D. J.; Morris, W.; Mondloch, J. E.; Kennedy, R. D.; Sarjeant, A. A.; Stern, C.; Hupp, J. T.; Farha, O. K.; Mirkin, C. A., Chem. Commun. 2015, 51, 6521-6523.

(27) Kennedy, R. D.; Krungleviciute, V.; Clingerman, D. J.; Mondloch, J. E.; Peng, Y.; Wilmer, C. E.; Sarjeant, A. A.; Snurr, R. Q.; Hupp, J. T.; Yildirim, T.; Farha, O. K.; Mirkin, C. A., Chem. Mater. 2013, 25, 3539-3543.

(28) Spokoyny, A. M.; Farha, O. K.; Mulfort, K. L.; Hupp, J. T.; Mirkin, C. A., Inorganica Chimica Acta 2010, 364, 266-271.

(29) Farha, O. K.; Spokoyny, A. M.; Mulfort, K. L.; Hawthorne, M. F.; Mirkin, C. A.; Hupp, J. T., J. Am. Chem. Soc. 2007, 129, 12680-12681.

(30) Farha, O. K.; Spokoyny, A. M.; Mulfort, K. L.; Galli, S.; Hupp, J. T.; Mirkin, C. A., Small 2009, 5, 1727-1731.

(31) Huang, S. L.; Lin, Y. J.; Yu, W. B.; Jin, G. X., ChemPlusChem 2012, 77, 141-147.

(32) Huang, S. L.; Weng, L. H.; Jin, G. X., Dalton Trans. 2012, 41, 11657-11662.

(33) Boldog, I.; Bereciartua, P. J.; Bulanek, R.; Kucerakova, M.; Tomandlova, M.; Dusek, M.; Machacek, J.; De Vos, D. E.; Base, T., CrystEngComm 2016.

(34) Rodríguez-Hermida, S.; Tsang, M. Y.; Vignatti, C.; C. Stylianou, K.; Guillerm, V.; PérezCarvajal, J.; Teixidor, F.; Vinas, C.; Choquesillo-Lazarte, D.; Verdugo Escamilla, C.; Peral, I.; Juanhuix, J.; Verdaguer, A.; Imaz, I.; Maspoch, D.; Planas, J. G., Angew. Chem., Int. Ed. 2016, accepted.

(35) Juanhuix, J.; Gil-Ortiz, F.; Cuni, G.; Colldelram, C.; Nicolas, J.; Lidon, J.; Boter, E.; Ruget, C.; Ferrer, S.; Benach, J., Journal of Synchrotron Radiation 2014, 21, 679-689.

(36) Bruker, A. S., V2012.2; Bruker AXS Inc.: Madison, WI, 2012.

(37) Sheldrick, G. M. S., Program for Empirical Absorption Correction of Area Detector Data; University of Göttingen: Göttingen, Germany, 2012.

(38) Sheldrick, G., Acta Crystallographica Section A 2008, 64, 112-122.

(39) Sheldrick, G., Acta Crystallographica Section C 2015, 71, 3-8.

(40) Di Salvo, F.; Paterakis, C.; Tsang, M. Y.; Garcia, Y.; Viñas, C.; Teixidor, F.; Giner Planas, J.; Light, M. E.; Hursthouse, M. B.; Choquesillo-Lazarte, D., Crystal Growth \& Design 2013, 13, 1473-1484.

(41) Han, L.; Xu, L.-P.; Qin, L.; Zhao, W.-N.; Yan, X.-Z.; Yu, L., Crystal Growth \& Design 2013, 13, 4260-4267.

(42) Spek, A. L., J. Appl. Crystallogr. 2003, 36, 7-13.

(43) Dolomanov, O. V.; Bourhis, L. J.; Gildea, R. J.; Howard, J. A. K.; Puschmann, H., J. Appl. Crystallogr. 2009, 42, 339-341.

(44) Addison, A. W.; Rao, T. N.; Reedijk, J.; van Rijn, J.; Verschoor, G. C., Journal of the Chemical Society, Dalton Transactions 1984, 1349-1356.

(45) Farha, O. K.; Malliakas, C. D.; Kanatzidis, M. G.; Hupp, J. T., J. Am. Chem. Soc. 2010, 132, 950-952.

(46) Burtch, N. C.; Jasuja, H.; Walton, K. S., Chem. Rev. 2014, 114, 10575-10612.

(47) Canivet, J.; Fateeva, A.; Guo, Y.; Coasne, B.; Farrusseng, D., Chem. Soc. Rev. 2014, 43, 5594-5617.

(48) Fox, M. A.; Hughes, A. K., Coordination Chemistry Reviews 2004, 248, 457-476.

(49) Planas, J. G.; Vinas, C.; Teixidor, F.; Light, M. E.; Hursthouse, M. B., Crystengcomm 2007, 9, 888-894. 
(50) Di Salvo, F.; Camargo, B.; Garcia, Y.; Teixidor, F.; Viñas, C.; Giner Planas, J.; Light, M. E.; Hursthouse, M. B., Crystengcomm 2011, 13, 5788-5806.

(51) Bahr, D. F.; Reid, J. A.; Mook, W. M.; Bauer, C. A.; Stumpf, R.; Skulan, A. J.; Moody, N. R.; Simmons, B. A.; Shindel, M. M.; Allendorf, M. D., Phys. Rev. B. 2007, 76, 184106.

(52) Graham, A. J.; Allan, D. R.; Muszkiewicz, A.; Morrison, C. A.; Moggach, S. A., Angew. Chem. Int. Ed. 2011, 50, 11138-11141.

(53) Tan, J. C.; Bennett, T. D.; Cheetham, A. K., Proc. Natl. Acad. Sci. U.S.A. 2010, 107, 99389943.

(54) Henke, S.; Li, W.; Cheetham, A. K., Chemical Science 2014, 5, 2392-2397. 